NBER WORKING PAPER SERIES

\author{
INFORMATION, TRADING AND \\ STOCK RETURNS: LESSONS FROM \\ DUALLY-LISTED SECURITIES
}

K.C. Chan

Wai-Ming Fong

René M. Stulz

Working Paper No. 4743
NATIONAL BUREAU OF ECONOMIC RESEARCH 1050 Massachusetts Avenue
Cambridge, MA 02138
May 1994

We are grateful to Yakov Amihud for comments, to Tom Gearge for useful discussions, and to Bong-Chan Kho for research assistance. This paper is part of NBER's research program in Asset Pricing. Any opinions expressed are those of the authors and not those of the National Bureau of Economic Research. 


\title{
INFORMATION, TRADING AND \\ STOCK RETURNS: LESSONS FROM \\ DUALLY-LISTED SECURITIES
}

\begin{abstract}
This paper compares the intra-day patterns on the NYSE and AMEX of volatility, trading volume and bid-ask spreads for European dually-listed stocks, Japanese dually-listed stocks also listed in London, and Japanese dually-listed stocks not listed in London with American stocks of comparable average trading volume and volatility. It is shown that the intra-day patterns for these stocks are remarkably similar even though the public information flows differ markedly across these stocks during the trading day. In the morning, Japanese stocks have the greatest volatility and volume, followed by European stocks and American stocks. These rankings are reversed in the aftemoon. We argue that these patterns are consistent with markets reacting to the overnight accumulation of public information which is greatest for Japanese stock and smallest for American stocks and inconsistent with the view that early morning volatility can be attributed to monopolistic specialist behavior.
\end{abstract}

K.C. Chan

Hong Kong University of Science \& Technology Clear Water Bay, Kowloon HONG KONG

René M. Stulz College of Business Ohio State University 1775 College Road Columbus, OH 43210 and NBER
Wai-Ming Fong Chinese University of Hong Kong Shatin, New Territories HONG KONG 


\section{Introduction.}

Considerable effort has been devoted recently to leaming about the determinants of stock retum volatility. This research has identified trading noise, public information, private information and trading mechanisms as potentially important determinants of the volatility of stock retums. To identify the relative importance of these determinants, contributions to the literature have focused mostly on experiments that exploit differences in trading mechanisms, in the amival of public information, and in whether markets are open. For instance, French and Roll (1986) use the suspension of trading on some Wednesdays in 1968 to compare non-trading days to trading days with similar rates of amival of public information. Barclay, Litzenberger and Wamer (1990) use Saturdays on the Tokyo stock exchange and U.S. retums of Japanese dually-listed stocks to investigate the impact of trading on volatility when public information arrival is reduced. Stolt and Whaley (1990) make the case that the opening mechanism of the NYSE increases stock retum volatility, whereas Amihud and Mendelson (1991) use the fact that the Tokyo stock exchange has two trading periods to argue that higher opening volatility is mostly the result of the incorporation of ovemight information. Foster and George (1992) use trading and non-trading period returns of dually-listed stocks and control stocks that trade only in the U.S. to argue that the greater volatility at the open is due to the accumulation of orders at the open. Papers in this literature focus on trading and nontrading period retums because there are no differences among stocks in the amival of public information during the trading period for the experiments they conduct.

In this paper, we investigate the determinants of stock retum volatility in a setting where the rate of arrival of public information differs predictably across stocks during the trading day. We compare the intraday retum behavior during the U.S. trading day of European, Japanese, and 
American stocks listed on the NYSE or the AMEX.' For European stocks, the arrival of public information drops off at the end of the moming in the U.S. as the European business day comes to an end. In contrast, for Japanese stocks, the arrival of public information is uniformly low during the U.S. trading day because the business day in Japan does not overlap with the trading day in the U.S. Hence, using these three classes of stocks, we compare stocks with very different pattems of public information arrival. Since the rate of public information arrival changes during the day across our sample, the sample is also well-suited to study the relation between the arrival of public information, volatility, trading volume, and bid-ask spreads. In particular, the sample is useful to address the issue of whether the arrival of public information leads to more trading, either because the arrivals of public and private information are correiated or because, as in the models of Varian (1989) and Harris and Raviv (1993), investors trade on public information because it changes their priors differentially.

If public information is an important determinant of volatility, one would expect European stocks to experience a drop in volatifity relative to American stocks when the European business day ends. We find that indeed more of the daily volatility of European stocks accrues during the moming than for American stocks with similar daily volume and volatility, but the difference is not statistically significant. The rate of accrual of volatility does not significantly differ between American stocks and European stocks in any of the four 65-minute trading periods from 10:35 to 14:55; further, the curnulative difference in the rate of accrual of volatility between European stocks and the American matching stocks never exceeds $2 \%$ of daily voiatility. When we turn to

\footnotetext{
' In an interesting recent paper, Kleidon and Wemer (1993) examine the intraday pattems of cross-listed U.K. stocks from the open in London to their close in the U.S. to understand better the implications of 24-hour trading of stocks. In their paper, they do not provide the comparisons across classes of stocks with different arrival rates of public information which are the focus of this paper. In this paper, we treat European stocks as a group and Japanese stocks as a group. Consequently, we do not investigate separately London-listed stocks. The results we report for the European sample are not inconsistent with those of Kleidon and Wemer (1993), though.
} 
Japanese stocks, these stocks also display higher volatility in the moming despite the fact that there is no reason to suspect that they would have more public information in the moming than their matching American stocks. After the first hour of trading, $40 \%$ of the daily volatility of Japanese stocks has accrued in contrast to $29 \%$ of the daily volatility of European stocks. American matching stocks, however, accrue significantly more volatility than Japanese stocks in every trading period from 10:35 to 14:55.

Our resulls raise two puzzles: (1) why do foreign stocks behave so much like comparable American stocks during the trading day and (2) why is the high volatility in the early moming trading in New York pervasive across stocks? Since the European and some Japanese stocks trade in Europe, there are observed foreign prices for most of the foreign stocks in our sample when New York opens and there is also a competing market for these stocks. The explanations for the higher volatility in the moming, such as price discovery or the role of the specialist imply that the abnomal early moming volatility should be smaller for foreign stocks, which we do not observe. Explanations which rely on private information trading also seem to be inappropriate here since one would expect private information to be more important in New York for domestic stocks.

We argue that trading on accumulated ovemight public information helps explain the puzzle that volatility and volume are high on foreign stocks early in the moming. If ovemight public information is incorporated in prices at the opening, one would expect less volatility and less volume on Japanese stocks than on their matching stocks early in the moming since the arrival rate of public information for these stocks is low relative to American stocks. in contrast, if there is uncertainty as to how American investors will react to the accumulated ovemight public information, the opposite is possible if the accumulated public information for Japanese stocks is more important than the accumulated public information accrued on American stocks and the 
public information accruing on these stocks earty in the moming. To understand this, suppose that stock trading is segmented, in the sense that investors trade a stock in their home country if they can. ${ }^{2}$ This means that American investors trade foreign stocks in New York if they are listed there. When New York opens, American investors therefore adjust their portfolios based on how the information that accrued ovemight affects their priors. Since markets have been open in the foreign countries after the previous close of New York trading. substantially more public information has accrued about foreign stocks than about domestic stocks. Hence, one would expect both more volatility and more trading for foreign stocks in the moming in reaction to the ovemight accumulation of public information. Since public information about American firms accrues at a higher rate during the day, one would expect more volatility and trading for these stocks later in the day. However, if American news is informative about foreign stocks, the differences in volatility and volume pattems between foreign and domestic stocks during the rest of the day are likely to be smaller than one would expect if American news conveys no information about foreign stocks, which helps explain why intraday day pattems are similar for domestic and foreign stocks.

The paper proceeds as follows. In section 2, we present our data and retums evidence. In section 3, we show the volatility pattems. In sections 4 and 5, we discuss respectively the evidence on volume and bid-ask spreads. We conclude in section 6.

\section{Section 2. Data and evldence on returns.}

The dataset we use is constructed as follows. Using the 1986 and 1987 ISSM tapes, we

\footnotetext{
${ }^{2}$ Kleidon and Wemer (1993) provide evidence that the London and New York markets are segmented, in the sense that they have separate, distinct intra-day pattems such that the New York intra-day pattem is not the continuation of the London intra-day pattem. Their concept of segmentation does not imply segmented trading, but segmented trading implies distinct intra-day pattems.
} 
select all listings under the names ADR, New York Shares and Cornmon Stocks from countries in the European time zone and from Japan. To be kept in the dataset, firms must have at least 6 trades a day on average, have 100 trading days in the year, and the lowest price in the year must be more than $\$ 3$. For each foreign firm, we select three matching domestic stocks which have similar trading activity in terms of the average daily number of trades, have similar standard deviations of hourly retums, and trade on the same exchange as the dual listed share. ${ }^{3}$ We drop all observations from October 14, 1987 to October 30, 1987. The Appendix lists our sample of foreign stocks and the matching stocks. We have 14 European stocks in 1986 and 21 in 1987. There are 5 Japanese stocks in the sample for 1986 and for 1987; of the Japanese stocks, 2 are listed in London in 1986 and in 1987.

To investigate intraday pattems, we treat the opening trade separately from the rest of the day that is divided in six equally spaced intervals of 65 minutes from 9:30 a.m. to 4.00 p.m. For the opening retum, we use the retum from the previous ovemight close to the first trade or to the mid-point of the first bid-ask quote, whichever is first observed. The retum for each interval is computed from the mid-point of the last bid-ask quote before the end of the previous interval to the mid-point of the last bid-ask quote of the interval. If the bid-ask quote does not change during the interval, the retum for the interval is set equal to zero. If the absolute value of the retum is greater than $50 \%$ during the interval, it is ignored.

For the variance estimates, we first compute the average retum, $r_{i}$ for each interval $i$ and each firm $j$ by taking the average of the retums $r_{p}$ across $T$ days, where $T$ is the number of days for which the retums are available. We then compute a squared retum adjusted for the average retum, $\left(r_{i}-r_{j}\right)^{2}$, which we call $V_{w}$. We average $V_{k}$ across firms of the same class in the sample

\footnotetext{
'We also compared intra-day pattems by matching ADRs with domestic stocks of similar volume only. Our conclusions are generally the same in that case.
} 
to obtain $V_{\text {fl }}$ for that class of firms. In this study, we use six different firm classes: European firms, Japanese firms, Japanese firms also listed in London, Japanese firms not listed in London, matching firms of European firms, and matching firms of Japanese firms.

To test for differences in intraday pattems between two classes of firms, we pair them in the following system of equations:

$$
\begin{aligned}
& v_{k}=b_{b} b_{0}+a_{k} \\
& V_{a}=\left(1-\sum_{j-1}^{6} b_{j}\right) b_{0}+\theta_{a} \quad i=0,1, \ldots, 5 \\
& v_{i}^{*}=\left(b_{1}+b_{i}^{*}\right) b_{0}^{*}+\theta_{n}^{*} \\
& V_{\dot{a}}^{*}=\left(1-\sum_{j=1}^{b}\left(b_{j}+b_{j}\right)\right) b_{i}^{\dot{0}}+\theta_{\dot{a}}^{\dot{0}}
\end{aligned}
$$

where $i=0$ corresponds to the open, and the variables and coefficients with an asterisk are for the second firm class. In this setting, the parameter $b_{0}$ is the total intraday variance excluding the opening variance. The $b$, coefficients, for $i=0,1, \ldots, 5$, measure the opening and intraday variance as a fraction of the total intraday vaniance, and the $b_{1}^{*}$ coefficients measure the vaniance differences between the first and the second firm class. This approach is inspired by the work of Foster and Viswanathan (1993). They estimate intraday pattems separately for each firm and then derive implications from the distribution of these pattems across firms. The small number of dually-listed firms prevents us from focusing on the distribution of intraday pattems across firms. Instead, we estimate the intraday pattems for each class of firms directly.

In estimating equations (1), we use Hansen's (1982) Generalized Method of Moments (GMM) procedure. We impose the following orthogonality conditions: 


$$
\theta_{T}(\mathrm{~b})=\frac{1}{T} \Sigma_{t-1}^{r}\left[\begin{array}{c}
\theta_{0 t} \\
\theta_{1 t} \\
\ldots \\
\theta_{t t} \\
\theta_{0 t}^{0} \\
\theta_{i t} \\
\cdots \\
\theta_{\theta t}
\end{array}\right]=0
$$

To estimate $b$, the vector of 14 unknown b coefricients, we minimize the quadratic form $g$ Wg, where $\mathbf{W}$, a symmetric weighting matrix, is a consistent estimator of the inverse of the asymptotic covariance matrix of $T^{1 / 2} g_{T}(\hat{b})$, where $b$ is the estimate of $b$, after adjusting for serial correlation as suggested by Newey and West (1987). Note that in (2), each equation describes the variance in an intraday period. Consequently, if there is autocorrelation in the residuals, it arises from the daily autocorrelation of the volatility for that intraday period. The correlation in volatility between intraday periods, or cross-correlation, is captured as cross-sectional covariance in the weighting matrix $W$. Though the system is just identified and our GMM estimates coincide with those of ordinary least squares, our standard errors are robust to heteroskedasticity, autocorrelation and cross-correlation between intra-day periods.

With $\boldsymbol{b}$ as the vector of estimates of $b$, and $\delta_{\boldsymbol{T}}$ as the consistent estimator of

$$
\frac{\partial g+(b)}{\partial b},
$$

we have

$$
\sqrt{T}(b-b)-N\left(0,\left[\delta_{T} w \delta_{T}\right]^{\dagger}\right)
$$

We test for the significance of the estimates using this covariance matrix.

Volume for an intraday interval refers to the normalized number of shares traded during that interval. We first calculate the number of shares traded over each interval. We then compute the firm average as the average across all intervals and all days. To obtain the normalized 
volume during an interval, we divide the number of shares traded over that interval by the firm average, and take the average across firms. To test for significance, we estimate equations (1) using the volume instead of the squared returns.

The bid-ask spread is measured as a percent of the bid-ask mid-point. It is observed at the market open and at the end of each trading interval. We then estimate equations (1) using the bid-ask spreads, but the estimated coefficients are scaled so that they can be interpreted as the bid-ask spread in an interval as a fraction of the bid-ask spread during the third trading interval (11:40-12:45).

Although our focus is not the intraday retums, we present evidence on these retums in table 1 and figure 1 for the sake of completeness. Intra-day retums follow a U-shaped pattem for all stocks similar to the one documented previously by Harris (1986). This reinforces one of the two puzzles we document, namely the similarity in intra-day pattems between domestic and foreign stocks trading in New York: all stock groups have a significant last interval retum. The overnight retum is positive for all stock groups, but significant for foreign stocks only. The other intra-day retums are insignificant except for the retum for European stocks in the first interval. Looking at the difference in retums between firm types, we find that European stocks have significantly lower retums in the first trading interval and significantly higher retums ovemight and in the fifth trading interval. Japanese stocks have a significantly higher retum than their matching stocks ovemight and in the last interval and do not have a significantly different retum from their matching stocks in any other interval. The Japanese stocks listed in London have a significantly higher retum in the third trading period than those which are not and have insignificantly different retums in all the other periods. 


\section{Sectlon 3. Intra-day volatllity patterns.}

Intra-day volatility patterns have been studied for U.S. stocks with the database we use. First, Wood, Mclnish and Ord (1985) using minute by minute transactions data show a U-shaped pattem for intra-day volatility. Harris (1986) also documents a strong U-shaped pattem for intraday volatility using 15-minutes retums. Finally, Foster and Viswanathan (1993) present results that are comparable to our study. They investigate the intra-day volatility for three groups of stocks. They divide the sample of NYSE stocks on the ISSM database that meet some selection criteria into deciles of trading activity and select $\mathbf{2 0}$ stocks in the first, fifth and tenth deciles of trading actifity. They show that, for all their deciles, there is significant intraday variation in volatility, with volatility being the highest during the first half-hour of trading. To make the first half-hour comparable to the other periods, they double its retum. They compare all trading intervals to the first half-hour and find that all intervals have a significantly lower variance than the first interval. For the first and tenth deciles, the coefficient estimates of regressions similar to (1) show a distinct U-shaped pattem, but no such pattem is present for the fifth decile.

Table 2 presents our coefficient estimates of equations (1). Since the fractions of intraday intervals sum to one, the coefficient for the last trading interval is just one minus the sum of the 5 previous intraday intervals and no individual t-test is possible for that interval. The results for European stocks are given in panel A. The estimates give the nomalized variance for an interval, defined as a fraction of the total intraday variance ignoring the close-to-open variance. It is immediately apparent that the variance fractions follow a U-shaped pattem during the day and this is confirmed in figure $2 A$. The close-to-open variance has the highest fraction and the fractions decline thereafter until the interval from 12:45 to 13:50. After this period, the fractions increase again. The same pattem holds for the domestic comparison stocks.

Table 2 makes it possible to compare per period the volatility pattems of the European 
in ovemight normalized variances is of the same magnitude as the differences in ovemight normalized variances for European stocks and their matching American stocks, which is significant. Hence, one can interpret this evidence as indicating that investors are more willing to trade at the open when a competing exchange is open. Two possible reasons for this are: (a) opening prices are less noisy or (b) trading is cheaper because of competition. Given that the rate of volatility accrual for Japanese stocks not listed in London is not higher following the open, it is hard to argue that the data is supportive of (a). To investigate (b), we have to look at bid-ask spreads which we do next.

\section{Section 5. BId-ask spread Intra-day patterns.}

We now tum to a comparison of the bid-ask intra-day pattems. Existing evidence for American stocks from Mclnish and Wood (1992). Hasbrouck (1991a,b) and Foster and Viswanathan (1993) indicates that there is a U-shaped pattem in bid-ask spreads. Foster and Viswanathan show that there are significant differences in adverse selection costs during the day, but that these differences are hard to reconcile with models of concentrated trading which suggest that the bid-ask spread should be lower when trading is highest. Their evidence is stronger for the most actively traded firms, however.

In table 7, we provide our evidence on intra-day pattems in bid-ask spreads. In panel A, we report the results for European stocks. The midday spread is lower for European stocks than in is for their matching American stocks. However, at the open, the normalized spread for European stocks, i.e., the spread divided by its midday value, is significantly higher than for American stocks: $17.2 \%$ versus $11.7 \%$. Hence, the existence of a competing market for the European stocks does not imply a smaller spike in spread in the moming, which makes it hard 
intraday volatility during the first trading interval even though, in contrast to the European and American stocks, their home business and trading days are over. As a result of this greater accrual of volatility in the first trading interval, Japanese stocks have significantly higher normalized volatility than their comparison group during that interval. In contrast, the comparison group has significantly higher normalized volatility over each of the subsequent four intervals and identical normalized volatility during the last interval. Hence, there is more evidence of differences in volatility pattems between Japanese and U.S. stocks than between European and U.S. stocks, in the sense of more intervals with significant differences. This is evidenced by the fact that the ratio of moming to aftemoon normalized volatility of Japanese stocks is significantly higher than the ratio of moming to aftemoon normalized volatility of matching stocks. Finally, for the Japanese stocks, the differences in normalized volatility are more economically significant: the fraction of intraday volatility that accrues to Japanese stocks in the first period of trading is almost $50 \%$ higher than the fraction that accrues to the comparison group of American stocks.

Table 3 provides a measure of how volatility accrues during the day which confirms the results of table 2. The volatility accrual rate for European stocks is faster than for their matching American stocks throughout the day until the last trading period, so that before the start of that period significantly more volatility has accrued for European stocks than for their matching American stocks. The volatility accrual rate for Japanese stocks is faster also, but it is also faster relative to European stocks. In contrast to European stocks, Japanese stocks accrue significantly more volatility than their matching American stocks early in the morning. At the end of the first three trading periods, the Japanese stocks have accrued significantly more volatility than their matching stocks. However, the difference in volatility accrual falls steadily during the day so that by the end of the fourth trading period the fraction of daily volatility accrued for Japanese stocks is indistinguishable from the fraction of daily volatility accrued for American stocks. 
There are several possible explanations for the evidence we uncover in tables 2 and 3. First, following Amihud and Mendelson (1991), one could argue that opening prices are noisy estimates of public information, so that the first hour of trading incorporates public information into prices that was already available at the opening. Since the Japanese business day closes after the end of the Japanese trading day, Japanese public information accrues after the close of the Irading day in Japan. For stocks not listed in Europe, this information can only be incorporated into prices when the NYSE opens. In contrast, for stocks listed in Europe, there is trading when the NYSE opens, so stock prices provide more precise estimates of the existing public information. The price discovery hypothesis suggests that moming volatility accrual should be less for the stocks listed in London. Panel $\mathrm{C}$ in table 2 explores this hypothesis by dividing the Japanese stocks into stocks listed in London and stocks not listed in London. In the first trading period, there is no difference between the two groups, whereas in the second period, Londonlisted stocks have higher normalized volatility than non-London listed stocks. This evidence does not support the price discovery hypothesis. The second trading period corresponds to the London close; hence, the Japanese stocks listed in London have an increase in volatility around the London close, so that their intra-day volatility in the U.S. inherits both the U-shaped pattem of London stocks and the U-shaped pattem of U.S. stocks. In contrast, but similarty to Kleidon and Wemer (1993), the European stocks do not exhibit an increase in volatility at the close of the European markets.

Since the New York specialist does not have a monopoly position at the opening for European stocks and for Japanese stocks listed in London, the higher first period normalized volatility can be attributed to specialist behavior only if one believes that American investors would not switch to the foreign market to avoid specialist rent-seeking. Whereas such a view is plausible given the higher transaction costs abroad, one would still expect to observe greater volatility for 
domestic stocks for the simple reason that there are fewer altematives for investors wishing to trade domestic stocks than for investors wishing to trade foreign stocks. Hence, it is hard to view our evidence as supportive of the argument advanced by Stoll and Whaley (1990).

It could well be that the massive ovemight amival of public information for foreign stocks is accompanied by an equally massive amival of short-lived private information. If this were the case, one would expect investors to trade on this private information early in the day. With this view, though, one would expect the volatility Increase to be smaller for Japanese stocks traded in London than for Japanese stocks not traded in London simply because some of the private information will be traded upon in London. As explained above, this is not the case.

The final explanation we consider is inspired by the trading models of Varian (1989) and Hamis and Raviv (1993). In these models, investors trade on public information because new information leads them to change their priors. Hence, American investors in Japanese or European stocks trade on the ovemight public information as the New York market opens if there is segmented trading. Since we don't assume that these investors have valuable private information which would be lost if they did not trade before New York opens, one would not expect them to use the London market. Since London trading does not reflect how American investors react to ovemight public information, the lack of a volatility difference in the first period of trading between Japanese stocks listed in London and those that are not can be understood with our explanation. If our explanation is correct, though, one would expect more trading early in the moming for foreign stocks. We tum to a comparison of intra-day patterns in volume next.

All the above analysis is done by computing retums using the mid-point between the bid and ask quotes. We interpret this mid-point as the efficient market price, so that changes in that mid-point correspond to the incorporation of new information into prices. It could be, though, that the mid-point moves around because of microstructural considerations, such as inventory 
concerns. This raises the question of whether these concems could make our inferences from the data invalid. One approach would be to follow the time-series analysis of Hasbrouck (1991a,b) and allow explicitly for a transitory component in the mid-point of the bid-ask quote. Instead, we show that our results about the similarity of the volatility pattems do not seem to depend on the use of the mid-point of the bid-ask quote. Panel A of table 4 shows results obtained using transaction prices. The intraday variance of transaction prices is higher because of bid-ask bounce. However, there seems to be no systematic microstructural effect which explains our results. The intraday pattems using transaction prices are mostly the same. In terms of the comparison between foreign and American stocks, the most pronounced effect of using transaction retums is for the first trading period for European stocks where the volatility difference is now significant and for the second trading period for Japanese stocks where it is no longer significant. As a result of these changes, the European stocks accrue significantly more volatility in the moming than matching American stocks. The differences between transaction retum volatilities and bid-ask midpoint volatilities are illustrated in panel $B$ of table 4 and figure 3 . There is a significant difference for the ovemight period, but no significant differences for the intraday periods for the dually-listed stocks, except for the fourth trading period for the Japanese stocks Ested on the LSE. Considering transaction retums has the effect of strengthening somewhat the result that European stocks have higher volatility than matching American stocks in the moming.

\section{Section 4. Intra-day patterns In volume.}

Jain and Joh (1988) report the hourly trading volume of the NYSE and demonstrate a Ushaped pattem in trading volume during the day. Foster and Viswanathan (1993) examine the intra-day volume pattem for top, bottom and middle deciles sorted by trading activity. They find intra-day differences in volume for all categories, but the differences are most pronounced for the 
most actively traded stocks. For all categories, though, the intra-day pattem has a U-shape with volume highest in the first half hour, falling until the fourth hour and then increasing again. The highest volume coincides with the highest variance, which is supportive of the model of concentrated trading of Admati and Pfleiderer (1988). Foster and Viswanathan (1993) investigate formally the relation between the regression coefficients of the volume regressions and of the volatility regressions. For deciles one and ten they find a significant positive relation between the coefficients of the two regressions.

In table 5 and figure 4, we present our results for the intra-day variation in volume. In panel $A$, we show the results for the European stocks. It is immediately clear that these stocks exhibit a U-shaped intra-day pattem and this is shown in figure 4A. One way to evaluate this pattem is by comparing a period's fraction of daily volume with the fraction of daily volume of the period from 11:40 to 12:45. When we perform this comparison, we find significant differences for all periods. European stocks have significantly more of their daity volume in the moming. American stocks have significantly more in the aftemoon, except in the last period. Relative to the period from 11:40 to 12:45, European stocks have significantly sharper peaks than matching American stocks. For instance, the first interval volume is 1.644 times the volume of the mid-day period for European stocks and 1.215 for matching stocks. The difference has a t-statistic of 8.116. For the last period, the ratios are respectively 1.297 and 1.379 , with a t-statistic for the difference of 1.642. To investigate further the concentration of trading, we compute Herfindahl indices as the sum of the squared volume accrual rates. This ratio would take a value of one if all trading is concentrated in one period and a value of $1 / 6$ if trading lakes place equally in each period. The Herfindahl index is 0.180 for European stocks and 0.172 for American matching stocks. Hence, both European and American stocks seem to have equally concentrated trading when measured this way. We saw in table 2 that the nomalized variance of European stocks 
exceeds the normalized variance of American comparison stocks by $1.9 \%$ of total intraday variance during the first trading interval; in contrast, the difference in volume is $4.6 \%$. Whereas European stocks have significantly higher volume in the moming, they have significantly lower volume in the aftemoon excepl during the last trading period where there is no difference between European and American stocks.

One might be tempted to attribute the differences in significance between tables 2 and 5 to differences in the power of the tests. It is true that differences between European and American firms of similar magnitudes are significant for normalized volume but not for normalized volatility. A closer look at the cumulative accrual of volume shows, however, that the volume and volatility pattems are quite different. The estimate of the cumulative difference in normalized volatility from 10:35 to $14: 55$ is zero whereas the estimate of the cumulative difference in normalized volume is $4.0 \%$ over that period. For the last trading period, table 2 documents a significant difference in normalized volatility, whereas it documents no significant differences in normalized volatility in the four previous periods. In contrast, the normalized volume difference is not significant for the last period and is significantly different for all the other periods.

Panel $\mathrm{B}$ of table 5 provides results for the Japanese stocks. For these stocks, we again observe a U-shaped pattem which is also apparent in figure 4B. This pattem is more pronounced than for American stocks: a higher fraction of Japanese stock trading accrues in the first and last trading intervals than for American slocks. For both the Japanese and matching American stocks, the fraction of daily volume which accrues during the last interval is roughly comparable to the fraction of daily volume which accrues during the first interval. The higher end-of-day volume of the Japanese stocks is not accompanied by higher volatility. Except for the last interval, though, Japanese stocks have greater volatility when they have greater volume. In contrast to the companison between European stocks and American stocks, the differences in volume are smaller 
than the differences in volatility: the fraction of volume that accrues to Japanese stocks in excess of the fraction of volume that accrues to American stocks during the first interval is only $3.7 \%$ of the daily total in contrast to $9.9 \%$ for the variance. The small differences explain why the Herfindahl ratio for trade concentration of Japanese stocks, 0.186 , is so close to the one for matching American stocks, 0.174. As for the comparison with European stocks, the Japanese stocks have lower normalized volume each period from 10:35 to 14:55 and higher normalized volume in the first and last interval.

Table 6 provides results on cumulative intraday volume. It shows that the normalized volume of American stocks catches up with the normalized volume of Japanese stocks more quickly during the day than it catches up with the normalized volume of European stocks. By 13:50, as much of the daily volume has accrued for American comparison stocks as for Japanese stocks; for European stocks, this occurs by 14:55. This evidence is consistent with the view that investors receive more information to trade upon late in the moming for European stocks than for Japanese stocks.

The private information story would suggest more accumulation of volume early in the day for Japanese stocks which do not trade on the London Stock Exchange. Panel $\mathrm{C}$ of tables 5 and 6 compares Japanese stocks listed in London with those that are not. There is some evidence that (1) stocks listed in London trade more at the open and (2) volume accumulates faster after the opening for stocks not listed in London. Interestingly, the greater normalized volume at the open for London-listed stocks is approximately offset by the lesser normalized volume of these stocks during the first two trading intervals. Hence, availability of the London market does lead to a shift in trading towards the open. This shift is not accompanied by a similar significant shift in variances: in table 2, the ovemight normalized variance for stocks traded in London is insignificantly higher and the first interval variance is insignificantly lower. Further, the difference 
in ovemight normalized variances is of the same magnitude as the differences in ovemight normalized variances for European stocks and their matching American stocks, which is significant. Hence, one can interpret this evidence as indicating that investors are more willing to trade at the open when a competing exchange is open. Two possible reasons for this are: (a) opening prices are less noisy or (b) trading is cheaper because of competition. Given that the rate of volatility accrual for Japanese stocks not listed in London is not higher following the open, it is hard to argue that the data is supportive of (a). To investigate (b), we have to look at bid-ask spreads which we do next.

\section{Section 5. BId-ask spread Intra-day patterns.}

We now tum to a comparison of the bid-ask intra-day pattems. Existing evidence for American stocks from Mclnish and Wood (1992). Hasbrouck (1991a,b) and Foster and Viswanathan (1993) indicates that there is a U-shaped pattem in bid-ask spreads. Foster and Viswanathan show that there are significant differences in adverse selection costs during the day, but that these differences are hard to reconcile with models of concentrated trading which suggest that the bid-ask spread should be lower when trading is highest. Their evidence is stronger for the most actively traded firms, however.

In table 7, we provide our evidence on intra-day pattems in bid-ask spreads. In panel A, we report the results for European stocks. The midday spread is lower for European stocks than in is for their matching American stocks. However, at the open, the normalized spread for European stocks, i.e., the spread divided by its midday value, is significantly higher than for American stocks: $17.2 \%$ versus $11.7 \%$. Hence, the existence of a competing market for the European stocks does not imply a smaller spike in spread in the moming, which makes it hard 
to explain this spike by the monopolist behavior of NYSE specialists. The normalized spread for European stocks falls continuously throughout the day, except for being higher in the interval from 13:50 to 14:55 than in the surrounding intervals. All aftemoon spreads are lower than at midday for European stocks and two are significantly lower. The last trading period spread is the lowest of the day and is significantly lower than the spread of the American matching stocks. As shown on figure 5, European stocks do not exhibit a U-shaped pattem of bid-ask spreads even though their volume and volatility do. The normalized bid-ask spread of European stocks is significantly higher than that of the matching stocks at the beginning of the day and significantly lower at the end of the day. Nevertheless, the matching stocks do not exhibit much of a U-shaped pattem either. the bid-ask spread of matching stocks at the end of the day is not significantly higher than the bid-ask spread at midday.

Panel B of table 7 and figure 5 provide evidence for Japanese stocks. Again, for these stocks the bid-ask spread at midday is lower than for the matching American stocks. The results early in the moming are similar to those shown in panel $A$, with a higher normalized spread for the Japanese stocks than for their matching American stocks. Contrary to the European stocks, though, the bid-ask spread for Japanese stocks at the end of the day is not significantly lower than at midday. There is no evidence that competition by foreign markets eliminates the higher bid-ask spread in the moming. The absence of a higher bid-ask spread at the end of the day cannot be attributed to competition since forelgn markets are closed at that time. Further, in our sample, the behavior of the Japanese stocks at the end of the day is not different from their matching stocks.

It is difficult to believe that the greater normalized spread of foreign stocks earty in the moming reflects greater adverse selection resulting from a higher probability that the specialist would end up trading with investors who have private information. This is because, presumably, 
private information trading is more likely to take place on the deeper home market of a security and during the foreign business day. It may well be, though, that in the moming, as American investors react to ovemight public information, there is a substantial risk for the specialist of large changes in his inventory resulting from changes in the American investors' demand for foreign securities. The specialist would prolect himself from such changes by posting a greater bid-ask spread.

\section{Section 6. Concluding remarks.}

In this paper, we investigate the intraday volatility, volume, and bid-ask spread pattems for stocks that differ markedly in the arrival rate of public information during the trading day. We Find that, in spite of the differences in the arrival rate of public information, all groups of stocks have U-shaped pattems of volume and volatility. The U-shaped pattems in volatility cannot be explained by the contemporaneous amival of public information for the different stocks. Models with trading on private information do not seem to be consistent with our results. This is because, for Japanese stocks, one would expect volatility to be less for the slocks listed in London than for the other stocks if private information is a major determinant of volatility because investors with private information presumably take advantage of the opportunity to trade in London. We find no support for this.

A plausible story for our results is that investors in the U.S. trade on the basis of the accumulated stock of public information since the last closing of the U.S. markets. This stock of information is the largest for Japanese stocks since a whole business day takes place between the close and open of U.S. markets, the second largest for European stocks since more than half a business day takes place between the close and open of U.S. markets, and smallest for American stocks. With this view, investors trade on public information because it changes their 
priors. The process of demand revelation causes prices to exhibit greater volatility. Consequently, the opening price is not a noisy estimate of the fundamentals known at the open; rather, the demand by American investors is revealed only over time as they react to the accumulated public information. The volatility of matching American stocks is lower in the moming because not much has happened to change investors' priors. Bid-ask spreads are larger in the morning for foreign stocks because there is more uncertainty about demand. The foreign stocks also have a trading concentration at the end of the day, but it is more likely due to random forces than to investors reacting to public information, since little public information has accrued on these stocks during the day. Hence, this concentration of trading does not lead to higher bid-ask spreads. Whereas one can understand the greater concentration of trading of foreign stocks early in the day, the concentration of trading towards the end of the day is a puzzle left for future research.

The great similarity of the intra-day pattems across European, Japanese and American stocks suggests that, once one compares stocks with similar volume and volatility, differences in the rate of amival of public information during the day, as opposed to ovemight, are not as important as expected. This result can be interpreted as evidence that news during the U.S. business day are sufficiently important for foreign stocks that they lead to intra-day pattems similar to those of U.S. stocks of similar volume and volatility. 


\section{References}

Admati, A., and P. Pfleiderer, 1988, A theory of intraday pattems: Volume and price variability. The Review of Financial Studies 1, 3-40.

Amihud, Y., and H. Mendelson, 1991, Efficiency and trading: Evidence from the Japanese stock market, The Joumal of Finance 46, 1765-1790.

Barclay, M.J., R.H. Litzenberger, and J.B. Wamer, 1990, Private information, trading volume, and stock retum variances, The Review of Financial Studies 3, 233-253.

Foster, M., and T. George, 1992, Volatility, trading mechanisms and intemational cross-listing. unpublished working paper, Ohio State University.

Foster, F., and S. Viswanathan, 1993, Variations in trading volume, retum volatility and trading costs: Evidence on recent price formation models, The Joumal of Finance 48, 187-211.

French, $K$. and R. Roll, 1986, Stock retum variances: The arrival of information and the reaction of traders, The Joumal of Financial Economics 17, 5-26.

Hansen, L., 1982, Large sample properties of generalized method of moment estimator. Econometrica 50, 1029-1054.

Hamis, L., 1986, A transactions data study of weekly and intradaily pattems in stock retums, Joumal of Financial Economics 16, 99-117.

Hamis, M., and A. Raviv, 1993, Differences of opinion make a horse race. The Review of Financial Studies 6, 473-506.

Hasbrouck, J., 1991a. Measuring the information content of stock trades, The Joumal of Finance 46, $179-207$.

Hasbrouck, J., 1991b, The summary informativeness of stock trades: An econometric analysis, The Review of Financial Studies 4, 574-595. 
Jain, P., and G. Joh, 1988, The dependence between hourty prices and trading volume, Joumal of Financial and Quantitative Analysis 23, 269-283.

Kleidon, A., and I. Wemer, 1993, Round-the-clock trading: Evidence from U.K, cross-listed securities, working paper, Stanford University, Stanford, CA.

Mclnish, T., and R. Wood, 1992, An analysis of intraday pattems in bid/ask spread for NYSE stocks, The Joumal of Finance 47, 753-764.

Newey, W., and K. West, 1987. A simple positive semi-definite heteroskedasticity and autocorrelation consistent covariance matrix, Econometrica 55, 703-708.

Stoll, H., and R. Whaley, 1990, Stock market structure and volatility, The Review of Financial Studies 3, 37-71.

Varian, H., 1989, Differences of opinion in financial markets, in Financial Risk: Theory, Evidence and Implications, Proceedings of the Eleventh Annual Economic Policy Conference of the Federal Reserve Bank of St. Louis, C. Stone, ed. (Boston: Kluwer Academic Publishers). 3-37.

Wood, R., T. Mclnish and J. Ord, 1985, An investigation of transactions data for NYSE stocks, The Joumal of Finance 40, 723-739. 


\section{Table 1. Returns (86-87)}

Intraday returns of domestic and foreign stocks trading in New York. The percentage return for each interval is computed with the bid-ask midpoints. The ratio, "Morning/Afternoon', is computed excluding the opening return. The t-statistics are obtained using the Newey and West (1987) method with 15 lags.

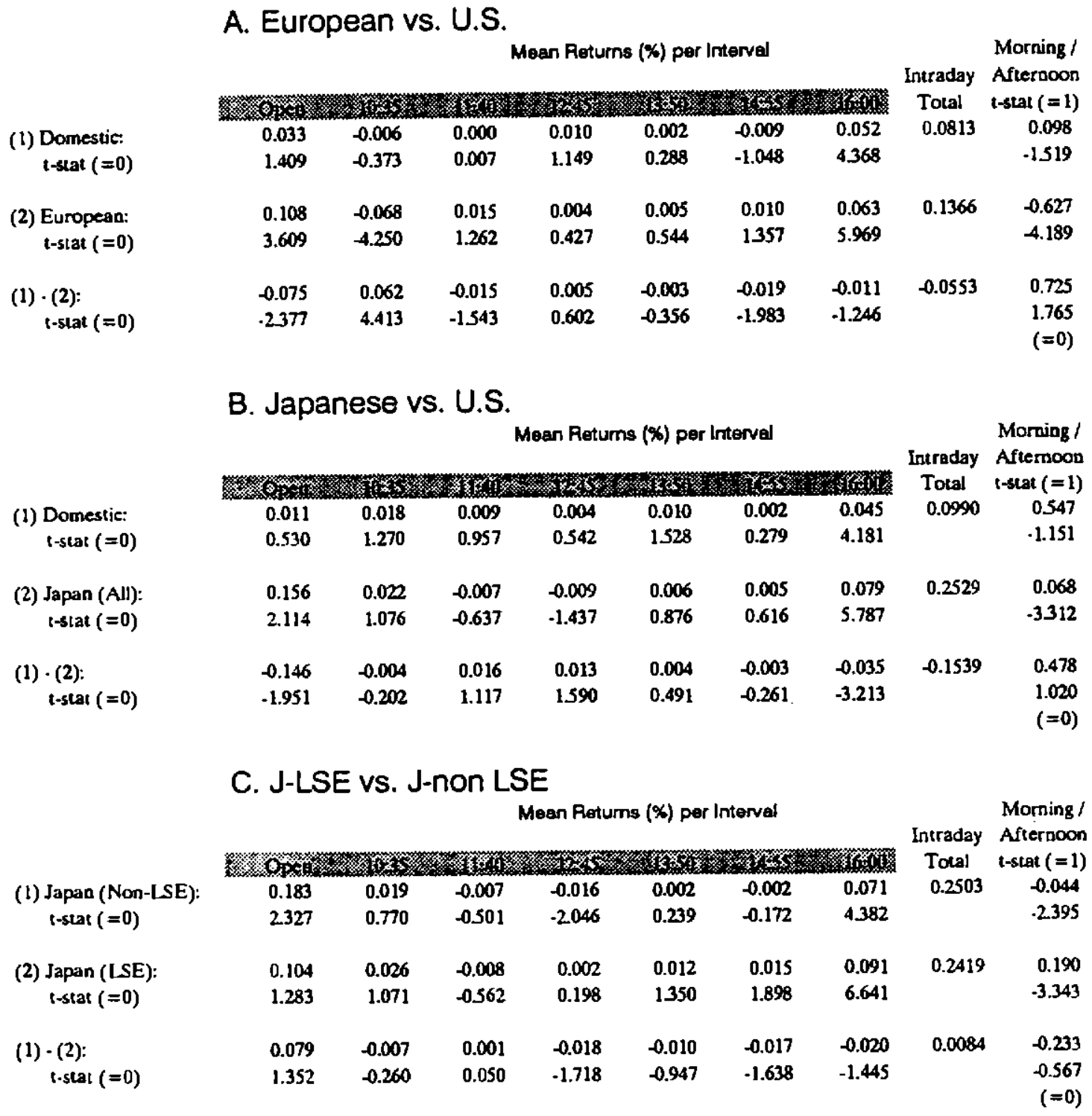




\section{Table 2. Variance (86-87)}

Intraday variances of domestic and foreign stocks trading in New York. Using the bid-ask midpoints, the normalized variance for each interval is computed as a fraction of the total intraday variance. The ratio, "Morning/Afternoon", is computed excluding the opering variance. The t-statistics are obtained using the Newey and West (1987) method with 15 lags.

\section{A. European vs U.S.}

(1) Domestic: t-stat $(=0)$

(2) European: tstat ( $=0)$

(1) - (2): t-stat $(=0)$

(1) Domestic: t-stat $(=0)$

(2) Japan (All): t-stat $(=0)$

(1) - (2): t-stat $(=0)$

\section{管

$$
0.380
$$

$$
0.79
$$$$
7.605
$$$$
-0.412 \quad-0.019
$$$$
-6.758 \quad-1.149
$$

$-1.149$

\section{Fraction of Intraday Total}

$7 \% 1 \mathrm{x}$

0.192

0.137

22735

0.106

20.909

0.149

0.104

17.798

14.031

$-0.013$

$-1.315$

0.002

0.292

0.603
B. Japanese vs. U.S.
Fraction of Intraday Tolal

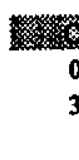

\section{.

-

0.121

17.427

0.122

10.993

$-0.002$

$-0.124$

0.173
Morning / Intraday Afternoon

Total t-teat $(=1)$

$0.00035 \quad 1.495$

$12.458 \quad 5.431$

$0.154 \quad 0.00026$

14.377

$0.019 \quad 0.00009$

$0.00009-0.134$

$-1.139$

(=0)

$\begin{array}{rrrrrrrrr} & \\ 0.443 & 0.274 & 0.174 & 0.150 & 0.112 & 0.117 & 0.173 & 0.00015 & 1.486 \\ 3.626 & 20.479 & 20.152 & 23.883 & 22976 & 23.460 & & 13.199 & 5.374 \\ & & & & & & & & \\ 5.638 & 0.403 & 0.143 & 0.106 & 0.084 & 0.098 & 0.165 & 0.00008 & 1.878 \\ 7.501 & 10.328 & 11.091 & 8.915 & 10.783 & 10.699 & & 11.590 & 4.497 \\ & & & & & & & & \\ -5.195 & -0.129 & 0.030 & 0.044 & 0.028 & 0.019 & 0.008 & 0.00006 & -0.392 \\ -6.977 & -3.251 & 1.877 & 3.423 & 3.111 & 1.864 & & & -2.029 \\ & & & & & & & & (=0)\end{array}$

C. J-LSE vS. J-non LSE

Fraction of Intradey Total

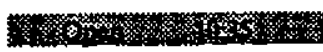

wa

(1) Japan (Non-LSE): t-stat $(=0)$

(2) Iapan (LSE): tstat (=0)

(1) - (2): t-stat $(=0)$

5.466

6.100

0.408

7.011

5.914

7.558

0.396

13.341

$-0.448$

$-0.523$
$0.012-0.036$

$0.187 \quad-1.929$

0.130

0.130
8.392

0.10

0.105
6.593

0.078

0.078
9.196

0.107

7.827

0.093

7.955

$-0.002$

$-0.108$

$-0.014$

$-1.114$

0.017
0.992

Morning /

Intraday Aftemoon

Total istat $(=1)$ $0.00009 \quad 1.798$

$8.660 \quad 2.895$

0.104

0.175

0.0008

2.017

$12.454 \quad 5.600$

$\begin{array}{lll}0.024 & 0.00001 & -0.219\end{array}$

$-0.703$

$(=0)$ 


\section{Table 3. Cumulative Variance (86-87): Excluding Open}

Cumulative intraday variances of domestic and foreigu stocks trading in New Yort. Using the bid-ask midpoints, the cumulative variance for each interval is computed as a cumulative fraction of the total intraday variance excluding the opening variance. The t-statistics are computed using the Newey and West (1987) method with 15 lags.

(1) Domestic: istat $(=0)$

(2) European: t-stat $(=0)$

(1) - (2): t-stat $(=0)$

Domestic

(2) Japan (All) t-stat $(=0)$

(1) - (2): t-stat $(=0)$

\begin{tabular}{|c|c|c|c|c|c|c|}
\hline \multicolumn{6}{|c|}{ Cumulative Fraction of Intraday Total } & \multirow{2}{*}{$\begin{array}{l}\text { Intraday } \\
\text { Total }\end{array}$} \\
\hline & & & & & & \\
\hline 0.270 & 0.462 & 0.599 & 0.706 & 0.827 & 1.000 & 0.00035 \\
\hline 19.662 & 30.160 & 40.918 & 53529 & 73.430 & & 12.458 \\
\hline 0.289 & 0.470 & 0.620 & 0.724 & 0.846 & 1.000 & 0.00026 \\
\hline 21.929 & 29.936 & 43.068 & 56.443 & 94.433 & & 14377 \\
\hline-0.019 & -0.008 & -0.020 & -0.018 & -0.019 & & 0.00009 \\
\hline-1.149 & -0.409 & -1.141 & -1.107 & -1.929 & & \\
\hline
\end{tabular}

B. Japanese vs. U.S.

Cumulative Fraction of Intradey Total

\begin{tabular}{|c|c|c|c|c|c|c|}
\hline & & & & & & \\
\hline 0.274 & 0.448 & 0.598 & 0.710 & 0.827 & 1.000 & 0.00015 \\
\hline 20.479 & 30.889 & 40.843 & 51.723 & 70.605 & & 13.199 \\
\hline 0.403 & 0.547 & 0.653 & 0.736 & 0.835 & 1.000 & 0.00008 \\
\hline 10.328 & 18.334 & 27.684 & 38.940 & 54.230 & & 11.590 \\
\hline-0.129 & -0.099 & -0.055 & -0.026 & -0.008 & & 0.00006 \\
\hline-3.251 & -3.055 & -2247 & -1.291 & -0.533 & & \\
\hline
\end{tabular}

C. J-LSE vs. J-non LSE

Cumulative Fraction of Intradey Total

$\begin{array}{lrrrrrrr}\text { (1) Japan (Non-LSE): } & 0.408 & 0.538 & 0.643 & 0.721 & 0.825 & 1.000 & 0.00009 \\ \text { t-stat (=0) } & 7.011 & 11.747 & 18.250 & 25.201 & 39.762 & & 8.660 \\ \text { (2) Japan (LSE): } & 0.39 & 0.562 & 0.669 & 0.761 & 0.849 & 1.000 & 0.00008 \\ \quad \text { t-stat (=0) } & 13.341 & 24.832 & 33.508 & 42.075 & 54.570 & & 12.454 \\ & & & & & & & \\ \text { (1) - (2): } & 0.012 & -0.024 & -0.026 & -0.040 & -0.024 & & 0.00001 \\ \text { t-stal (=0) } & 0.187 & -0.479 & -0.676 & -1.235 & -1.088 & & \end{array}$




\section{Table 4. Variance (86-87): Using Transaction Prices}

Intraday variances of domestic and foreign stocts uradiag in New York. Using the transaction prices, panel A shows the norm. -alized variance for each interval computed as a fraction of the totel iatraday variance. Panel B stows the difference from the results obtained using the bid-ask midpoints is Table 2 The ratio, 'Morning/Afternoon', is computed excluding the opening variance. The t-statistics are obtained using the Newey and West (1987) method with 15 lags.

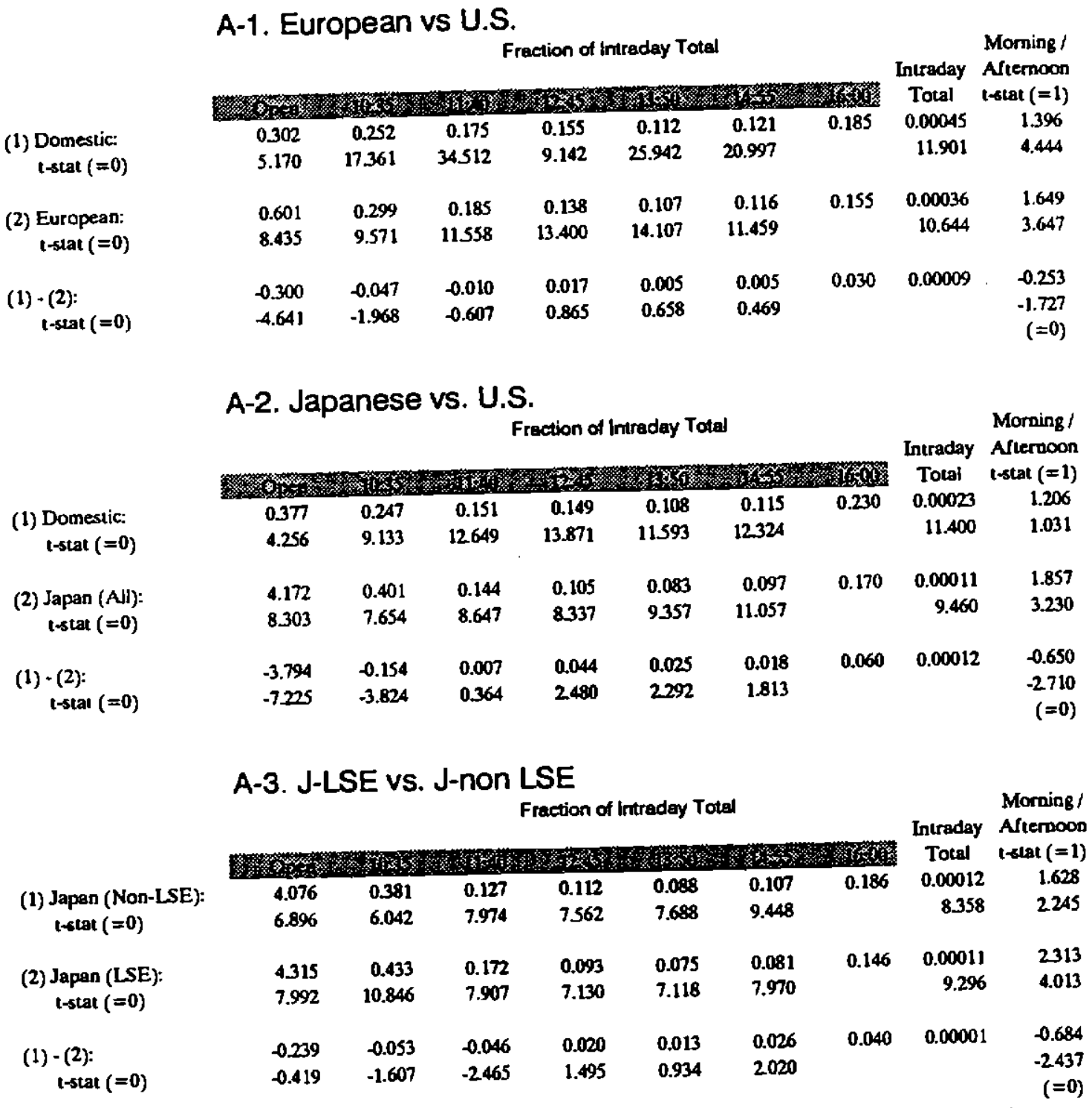


Table 4. (Continued)

\begin{tabular}{|c|c|c|c|c|c|c|c|c|c|}
\hline \multirow{3}{*}{$\begin{array}{l}\text { (1) Domestic } \\
\text { t-stat }(=0)\end{array}$} & \multicolumn{7}{|c|}{ Frection of Intradey Totel } & \multirow{2}{*}{$\begin{array}{l}\text { Intraday } \\
\text { Total }\end{array}$} & $\begin{array}{l}\text { Morning / } \\
\text { Afternoon } \\
\text { tstat }(=0)\end{array}$ \\
\hline & & & & & AMas & 0000 & -0.011 & & 0.098 \\
\hline & $\begin{array}{l}0.081 \\
2129\end{array}$ & 1.321 & 0.807 & -1.058 & .1 .292 & 0.055 & & & 1.443 \\
\hline (2) European: & 0.187 & -0.012 & -0.004 & 0.013 & $\begin{array}{l}-0.003 \\
-0.328\end{array}$ & $\begin{array}{l}0.007 \\
0.731\end{array}$ & -0.001 & -0.00010 & $\begin{array}{l}-0.019 \\
-0.111\end{array}$ \\
\hline t-stat $(=0)$ & 3533 & -0.356 & -0.209 & 1.182 & -0.300 & 0.731 & & & \\
\hline
\end{tabular}

(1) Domestic:

tetat $(=0)$

(2) Japad (Aلl):

t-stat $(=0)$

3.533

$-0.356 \quad-0.259$

$\begin{array}{lll}1.182 & -0.328 & 0.731\end{array}$

0.111

B-2. Japanese vs. U.S.

\begin{tabular}{|c|c|c|c|c|c|c|c|c|}
\hline \multicolumn{7}{|c|}{ Fraction of Intradoy Total } & \multirow{2}{*}{$\begin{array}{l}\text { Intraday } \\
\text { Total } \\
-0.00008\end{array}$} & \multirow{2}{*}{$\begin{array}{c}\text { Morning / } \\
\text { Afternoon } \\
\text { t-stat }(=0) \\
0.372\end{array}$} \\
\hline $0 \times$ & & $0 \mathrm{mon}$ & (1) & 004 & 0.00 & -0.058 & & \\
\hline 0.784 & 0.982 & 1.901 & 0.123 & 0.466 & 0.299 & & & 3362 \\
\hline 1.462 & 0.003 & -0.001 & 0.001 & 0.001 & 0.002 & -0.005 & -0.00003 & 0.013 \\
\hline 3.219 & 0.039 & -0.066 & 0.086 & 0.084 & 0.159 & & & 0.040 \\
\hline
\end{tabular}

\section{B-3. J-LSE vs. J-non LSE}

Fraction of intradey Total

Morning / Intraday Afternoon

(1) Japan (Non-LSE): t-stat $(=0)$

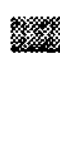

(2) Japan (LSE): totat $(\approx 0)$

$\begin{array}{lllllllll}2 & \\ 1.390 & 0.027 & 0.003 & -0.007 & -0.009 & -0.002 & -0.011 & -0.00003 & 0.170 \\ 2451 & 0.301 & 0.169 & -0.418 & -0.67 & -0.158 & & & 0.426 \\ 1598 & -0.037 & -0.007 & 0.014 & 0.018 & 0.007 & 0.005 & -0.00003 & -0.296 \\ 3.315 & -0.925 & -0.367 & 1.122 & 2.42 & 0.684 & & & -0.961\end{array}$




\section{Table 5. Normalized Volume (86-87)}

Intraday variation in volume of domestic and foreign stocks trading in New York. The normalized volume for each interval is $\infty_{0}$ puted as the number of shares traded over the interval divided by the average of all intervals. The ratio, "Morning/Afternoon", is Preded excluding the opening volume. The t-statistics are obtained using the Newey and West (1987) method with 15 lags.

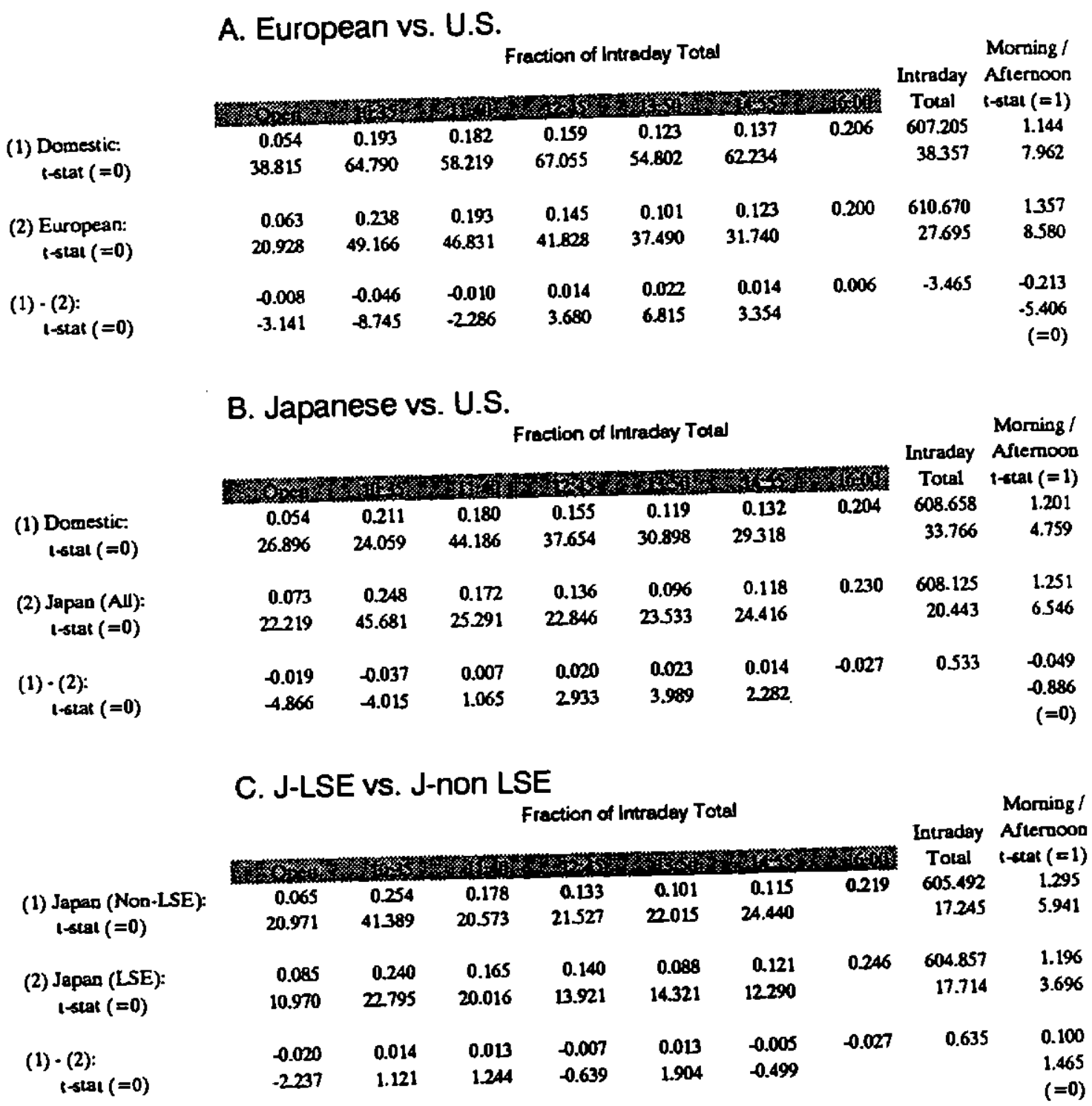


Table 6. Cumulative Normalized Volume (86-87): Excluding Open Intraday variation in cumulative volume of domestic and foreige stocks trading in New York. The cumulative volume for each interval is computed as a cumulative fraction of the intraday total volume carludith 15 lags.

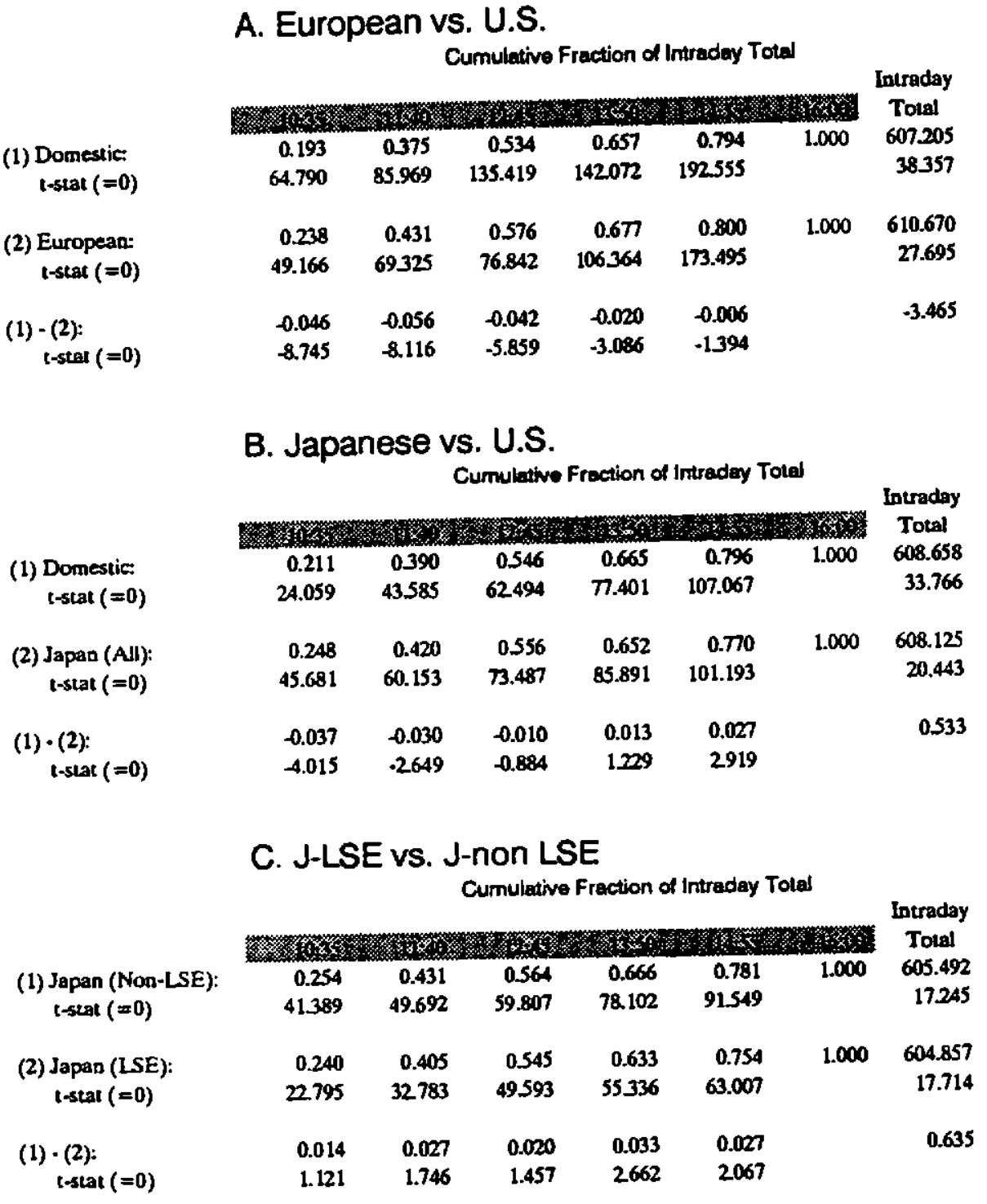




\section{Table 7. Bid Ask Spread Relative to Midday (86-87)}

Intraday patterns in bid-ask spreads of domestic and foreiga stocks trading in New York. The bid-ask spread for each interval is measured as a percent of the bid-ask midpoint at the end of each interval, and reported below as a fraction of the bid-ask spread for the third trading interval (11:40 - 12:45). The t-statistics are obtained using the Newey and West (1987) method with 15 lags.

\begin{tabular}{|c|c|c|c|c|c|c|c|c|}
\hline \multirow[t]{2}{*}{ percent of price } & \multicolumn{7}{|c|}{ A. European vs. U.S. } & \multirow{2}{*}{$\begin{array}{l}\text { Midday Spread } \\
\text { t-stat }(=0)\end{array}$} \\
\hline & 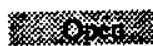 & 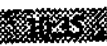 & 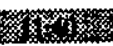 & 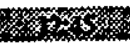 & 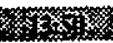 & 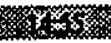 & 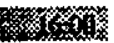 & \\
\hline (1) Domestic: & 1.117 & 1.035 & 1.008 & 1 & 0.998 & 0.997 & 1.008 & 1.022 \\
\hline t-stat $(=1)$ & 23.705 & 10.082 & 2300 & & -0.726 & -1.046 & 1.286 & 37.370 \\
\hline $\begin{array}{l}\text { (2) European: } \\
\text { t-stat }(=1)\end{array}$ & 1.172 & 1.040 & 1.015 & 1 & 0.989 & 0.999 & 0.974 & 0.890 \\
\hline & 23.134 & 6.557 & 2520 & & -2026 & -0.151 & 4.803 & 37.398 \\
\hline (1) - (2): & -0.055 & -0.004 & -0.008 & $\mathbf{0}$ & 0.009 & -0.002 & 0.035 & 0.131 \\
\hline tstat $(=0)$ & -5.942 & -0.594 & -1.134 & & 1.548 & -0.308 & 5.110 & \\
\hline percent of price & \multicolumn{7}{|c|}{ B. Japanese vs. U.S. } & \multirow{2}{*}{$\begin{array}{l}\text { Midday Spread } \\
\text { t-stat }(=0)\end{array}$} \\
\hline (1) Domestic. & 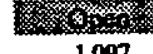 & 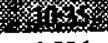 & 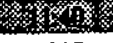 & 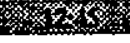 & 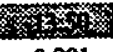 & 0.991 & $\frac{0.997}{0.100}$ & \\
\hline t-stat $(=1)$ & $\begin{array}{r}1.097 \\
17.760\end{array}$ & $\begin{array}{l}1.026 \\
5.204\end{array}$ & 0.997 & 1 & $\begin{array}{r}0.991 \\
-2344\end{array}$ & $\begin{array}{r}0.991 \\
-1.902\end{array}$ & $\begin{array}{r}0.997 \\
-0.509\end{array}$ & $\begin{array}{r}0.914 \\
36.691\end{array}$ \\
\hline & & & 103 & & $0 \infty 1$ & 0.974 & 0.992 & \\
\hline t-stat $(=1)$ & $\begin{array}{l}1.241 \\
9.420\end{array}$ & $\begin{array}{l}1.036 \\
4.666\end{array}$ & $\begin{array}{l}1.003 \\
0.274\end{array}$ & 1 & $\begin{array}{r}0.991 \\
-1.047\end{array}$ & -3.119 & -0.839 & $\begin{array}{r}0.490 \\
45.003\end{array}$ \\
\hline (1) - (2): & -0.144 & -0.031 & -0.006 & 0 & 0.001 & 0.017 & 0.005 & 0.424 \\
\hline istat $(=0)$ & -5.601 & -2539 & -0.551 & & 0.078 & 1.682 & 0.398 & \\
\hline percent of price & \multicolumn{7}{|c|}{ C. J-LSE vs. J-non LSE } & \multirow{2}{*}{$\begin{array}{l}\text { Midday Spread } \\
\text { t-stat }(=0)\end{array}$} \\
\hline & an & $x$ & ter & 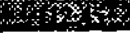 & & & & \\
\hline $\begin{array}{l}\text { (1) Japan (Non-LSE): } \\
\text { t-stat }(=1)\end{array}$ & $\begin{array}{l}1.235 \\
7.324\end{array}$ & 1.045 & 0.993 & 1 & 0.987 & 0.976 & 0.989 & 0.483 \\
\hline & 7.324 & 2.658 & -0.422 & & -1.068 & -2.206 & -0.791 & 43.903 \\
\hline $\begin{array}{l}\text { (2) Japan (LSE): } \\
\text { t-tat }(=1)\end{array}$ & 1.247 & 1.072 & 1.019 & 1 & 0.997 & 0.972 & 0.997 & 0.501 \\
\hline totat $(=1)$ & 7.694 & 4.207 & 1.076 & & -0.204 & -1.740 & -0.145 & 34.907 \\
\hline (1) - (2): & -0.012 & -0.027 & -0.026 & $\mathbf{0}$ & -0.010 & 0.005 & -0.009 & -0.018 \\
\hline i-stat $(=0)$ & -0.311 & -1.060 & -0.992 & & -0.509 & 0222 & -0.314 & \\
\hline
\end{tabular}


Figure 1. Returns (86 - 87)

A. Domestic vs. European

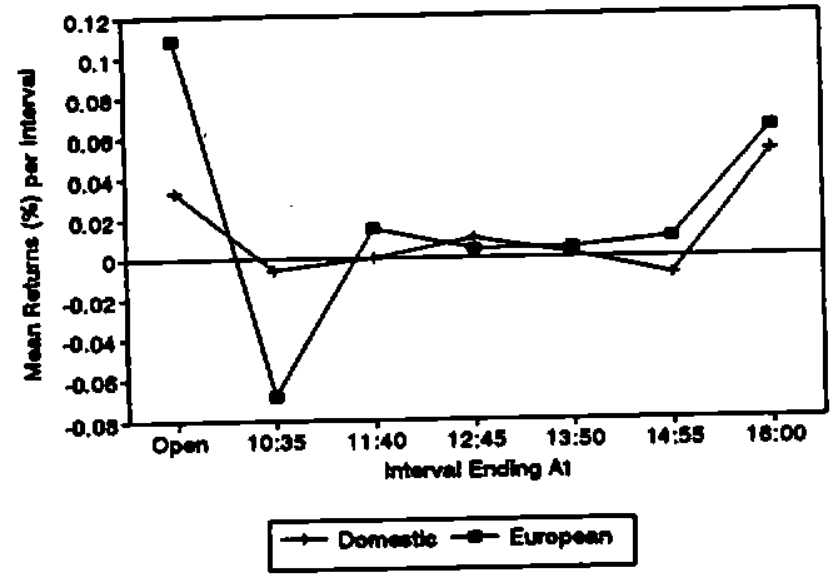

B. Domestic vs. Japan

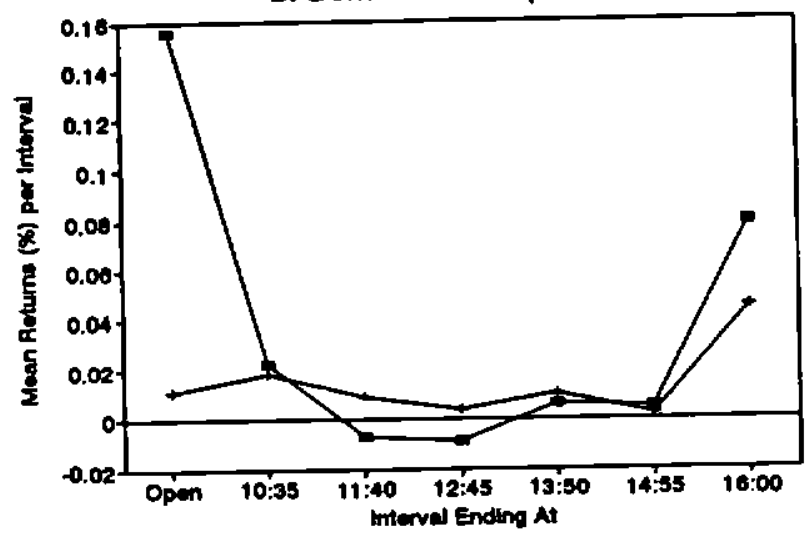

$\rightarrow$ Domestic $\rightarrow$ Jepan

C. Japan (non-LSE) vs. Japan (LSE)

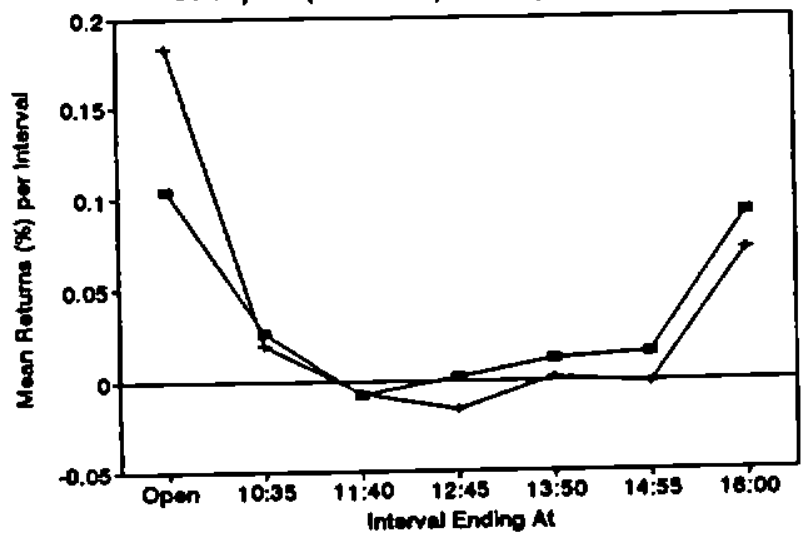

$\rightarrow$ Japan (Non-LSE - Japan (LSE) 
Figure 2. Variance (86-87)

A.Domestic vs. European

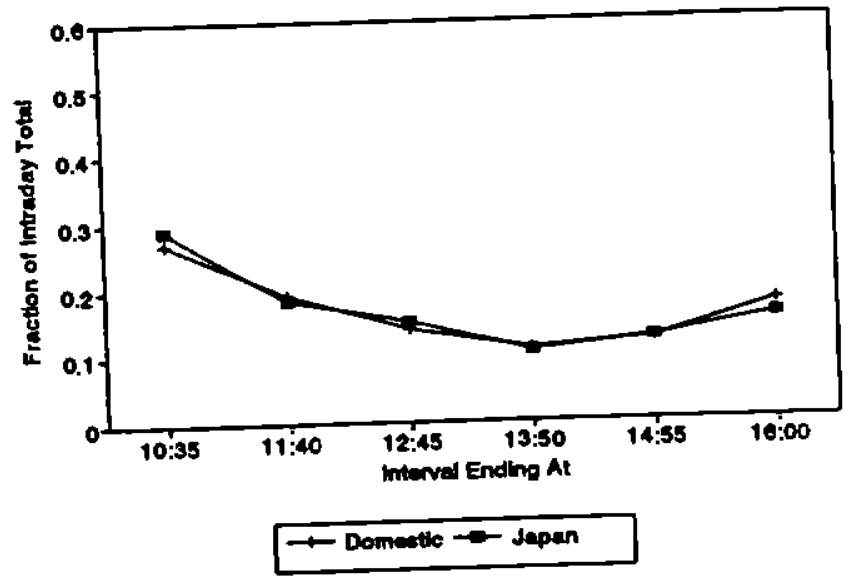

B. Domestic vs. Japan

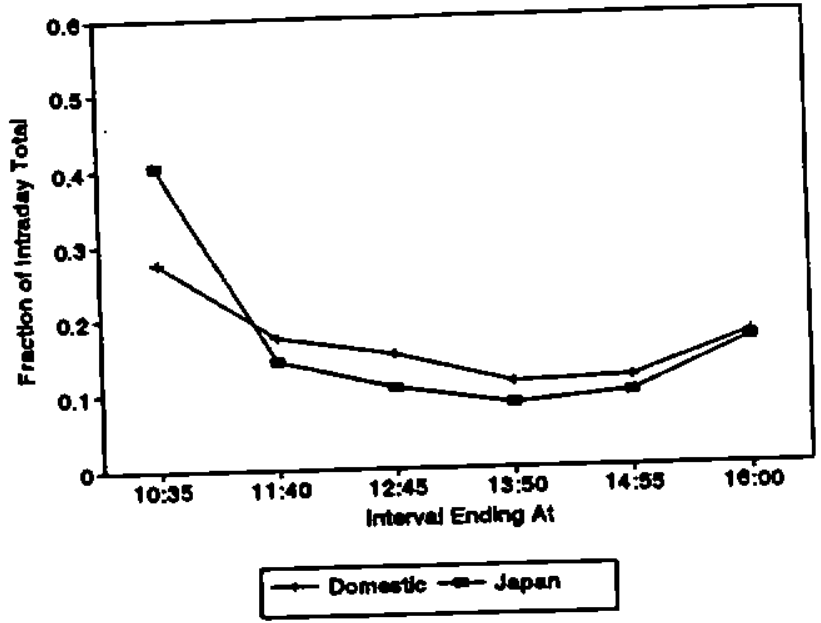

C. Japan (non-LSE) vs. Japan (LSE)

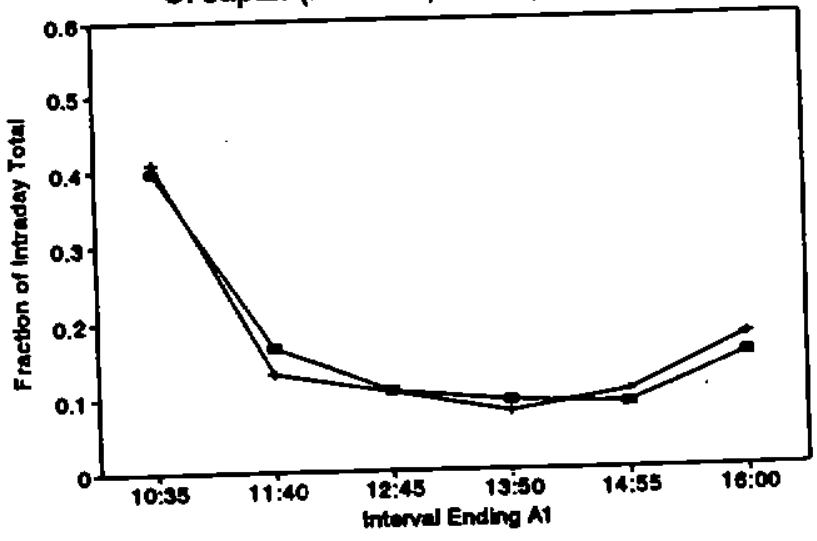

$\rightarrow$ Domeotic $\rightarrow$ Japan 
Fig 3. Midpoint Var - Transactions Var

A. Domestic vs. European

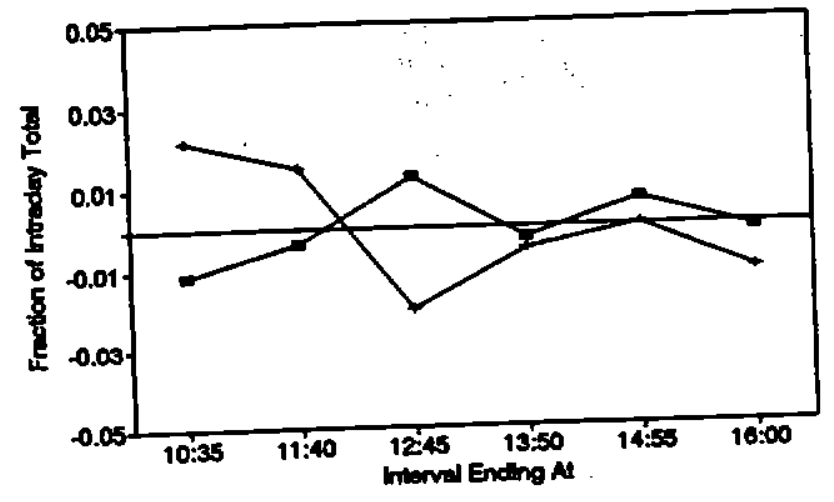

tr Dorivile $\rightarrow$ Emopean

B. Domestic vs. Japan

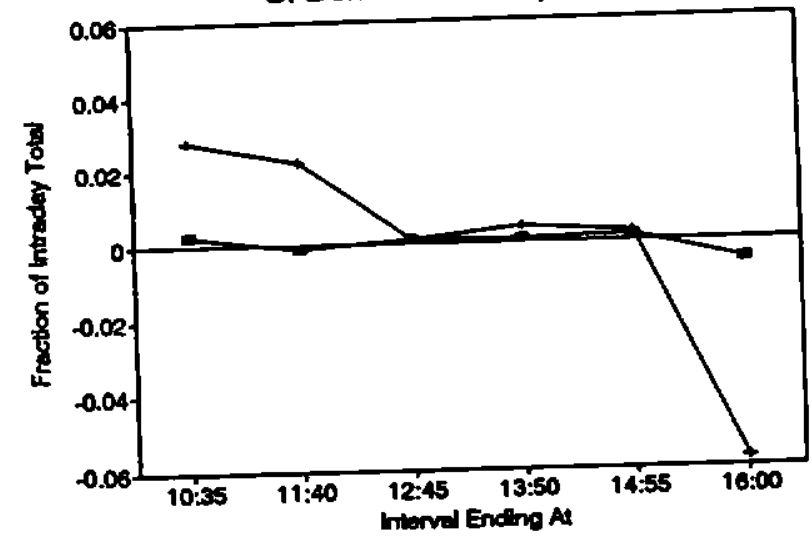

$\rightarrow$ Dometio - Jepen

C. Japan (non-LSE) vs. Japan (LSE)

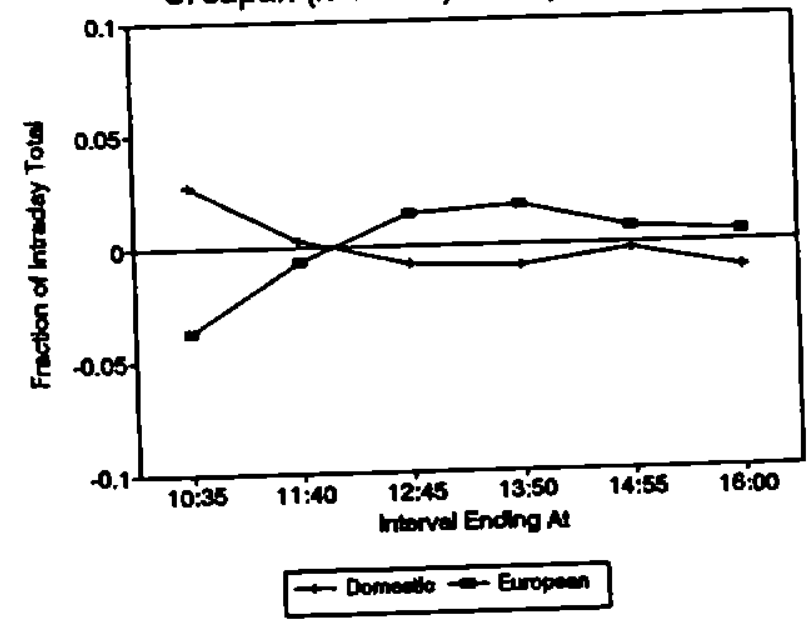


Figure 4. Normalized Volume (86 - 87)

A. Domestic ve. European

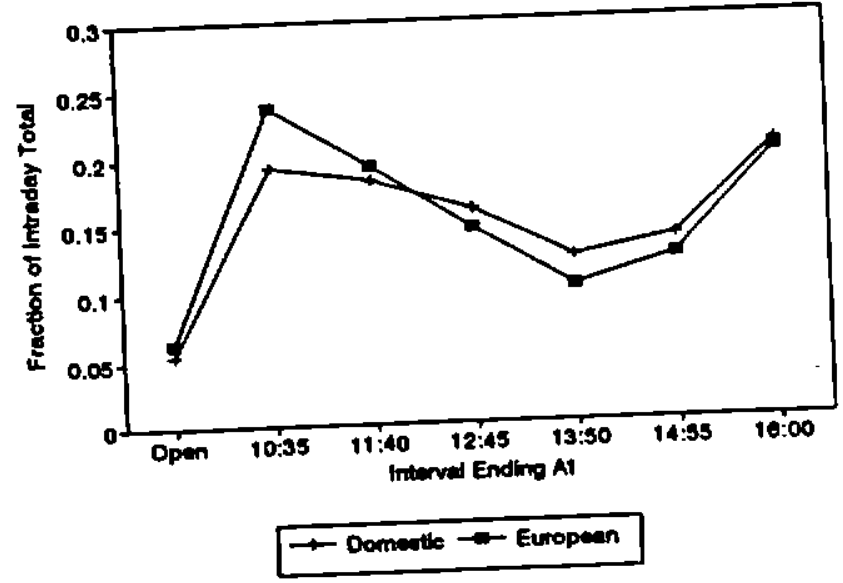

B. Domestic vs. Japan

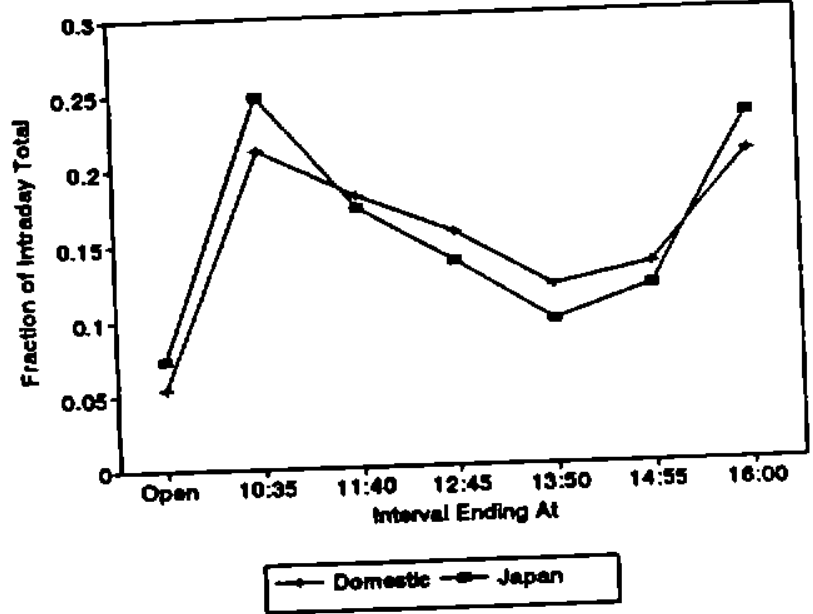

C. Japan (non-LSE) vs. Japan (LSE)

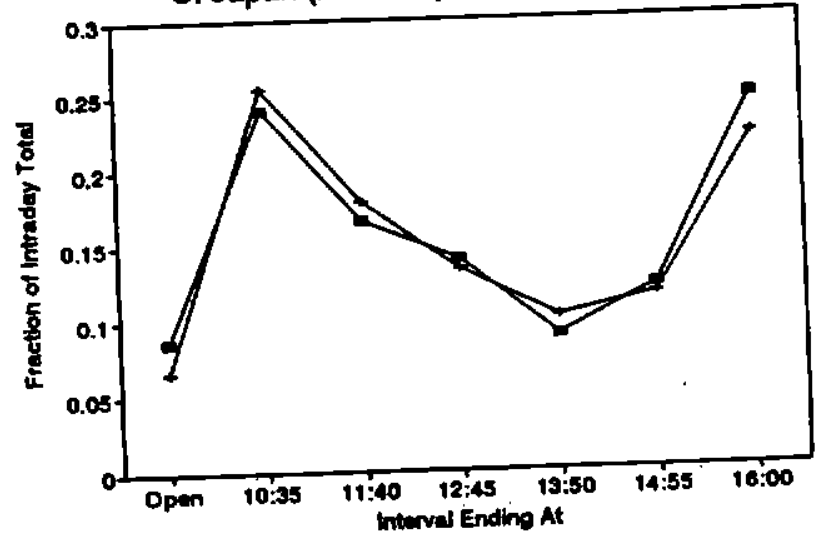

$\rightarrow$ Japen (Non-LSa) - Japan (LSE) 
Fig 5.Bid-Ask Spread Relative to Midday

A. Domestlc ve. European

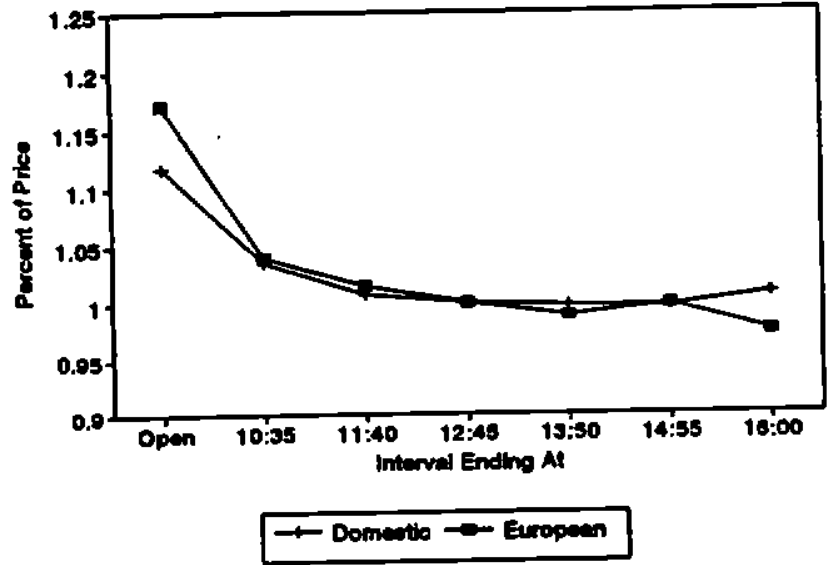

B. Domestic vs. Japan

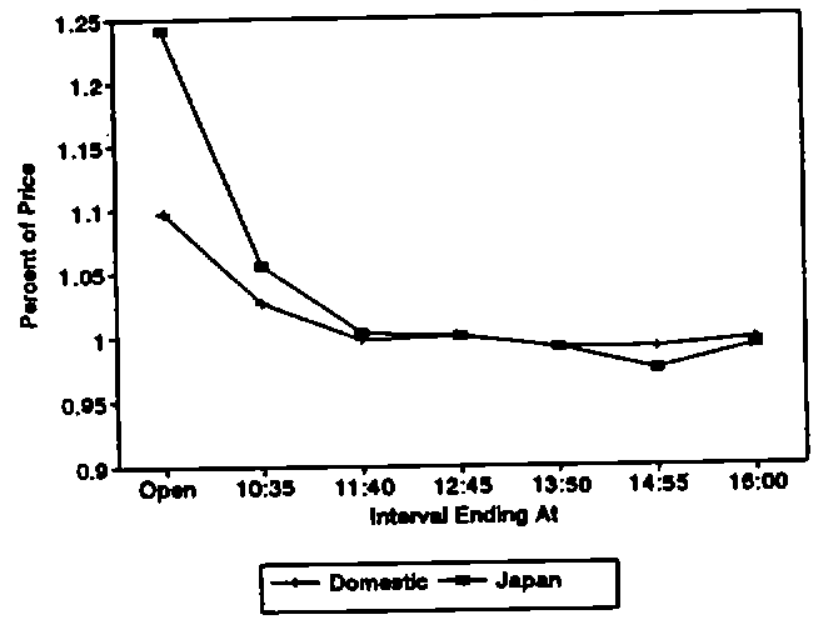

C. Japan (non-LSE) vs. Japan (LSE)

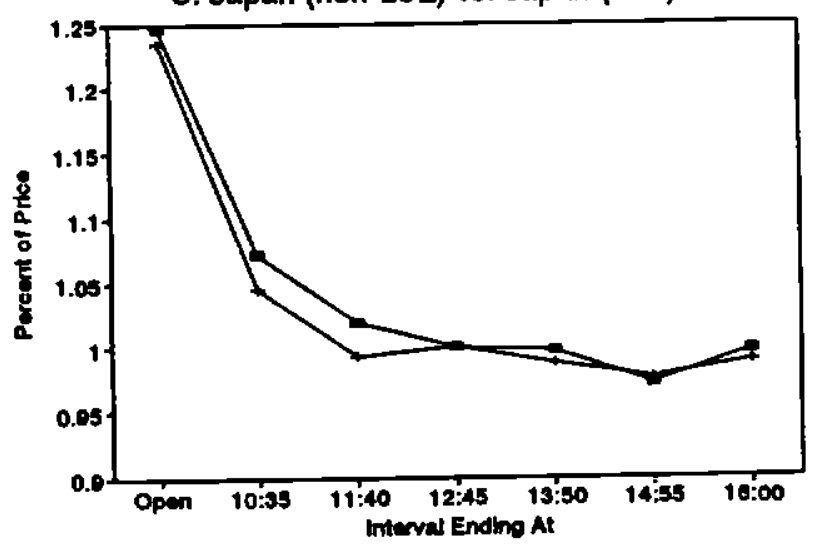

$\rightarrow$ Japen Pronlsa $\rightarrow-$ Japen fSG 


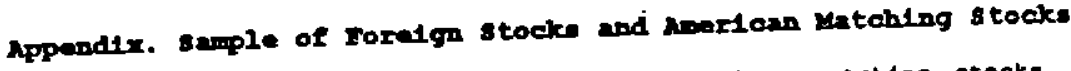

anple and lts three Anerican matching stocks, this toble For each forelgn atock in the rample and the cusip number, the number of trading days lor provides the ticker aymbol, the tirm nans, tho custe number, che number of trading returna, the provides, the average number of trades par day, the standard deviation of hourty ret number of shares

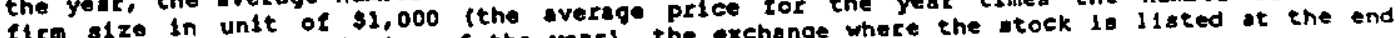

outetanding at the beginning of the yescl, the exchange where ehe etosk to to year.

A1. Euxopean stocks I1sted in NYSE/AMEX in 1906

\begin{tabular}{ll}
\hline OBS SYM. \\
1 & ASA \\
2 & NIS \\
3 & BP \\
4 & BTI \\
5 & GTY \\
6 & ET2 \\
7 & ICI \\
9 & KLM \\
9 & LAS \\
10 & NHY \\
11 & NVO \\
12 & RD \\
13 & SC \\
14 & UN
\end{tabular}

NAME

ASA LTD

NUSTMONT COMPO $N \mathrm{~V}$

BRITISH PETE LTD

A T IN

ET2 IAVUD LTD

TMPERIAL CKEM INDS PLC

MM ROYAL DUTCH AIRLS

LASER INDS LTD

NORSK HYDRO A $\mathbf{s}$

NOVO INDUSTRI A

RHELL TRANS \& TRADING LTD

UNILEVER N V
CUSIP

00205020

05212510

11086940

05527020

11102130

29780210

45270450

46251610

51006120

65653160

67010020

78025760

82270350

90478450
DAYS

236
236
236
236
233
236
236
236
236
118
236
236
236

$36 \quad 39.33$

NTPD

92.14

30.15

13.13

6.67

16. 32

30.05

5.66
$236 \quad 35.39$

Arerfean Matchlng stocks In 1906

CLX

CLOROX CO

HERCULES INC

NES NEW ENGLAND ELEC SYS

N1N NLLEN GROUP INC

ELE.

NEI

IOR

3 IWG

GLCTROSPACE SYS INC

NBI INC

IONA RES INC

IONA ILL GAS \& ELEC CO

WISCONSIN PWR \& LT CO

HUDSCN FOODS INC

MATRIX CORP N J

OZARK HLDGS INC

RANDNE INC

CYCLOPS CORP

WTCOR INC

HANDYMAN CORP

JACOES ENGR GROUP INC

TRIDEX CORP

SOUTHWESTERN PUB SVC CO

TECO ENEROY INC

WISCONSIN ELEC PWR CO

CASTERN CAS - TUEL NSSOC

INGERSOLL RNND CO

SEA LD CORP

GREENMAN BROS INC

HERITAGE ENTTI INC

NETMARK \& LEWIS INC

CECO IND

CINCINNATI BELL INC

unctede Ghs $C$

BLOCK H \& R INC

OUAKER ST OIL REDNG CORP

RITE AID CORP

MMERICN INPO TECHS CORP

CONSOLIDATED EDISCN $C O$ N Y I

SOUTHWESTERN BELL CORP

CENTEL CORP

LOUISVILLE GNS a ELEC CO

MAPCO INC

MISTED INDS INC

ORANGE G ROCKAND UTILS INC

SOUTHEST GAS CORP
26905410 42705610

64400210

01763420

28616210

62873510

46253710

16247010

97682610

44378210

57602910

69263210

05982510

23252510

92925310

42033510

46981410

69590610

04574320

67237510

97665610

27646110

45696610

61140810

39537020

42722710

65157610

15003620

17187010

50558810

09367110

74741910

26775410

02600410

20911110

04533310

15133410

54667610

56509710

03217710

60406510

04469510
63.28

92.02

77.18

23.67

17.70

25. 89

32.04

25.97

32.21

43.74

53.61

49.64

15. 31

11.30

14.17

6.31

6.01

6.91

65.27

67.51

67.51

60.44
46.79

46.79
39.14

37.81

34.69

29.80

31.49

24.14

16.70

13.28

52.41

41.74

50.00

136.91

124.03

154.61

41. 61

43,51

38.09

40.60

31.62

34.96
Std Dev.

0.005563

0.008601

.003672

0.006001

0.004264

0.021465

0.003337

.005569

0.012002

0.004822

0.006409

0.003106

.003527

0.003406

0.005585

0.05570

0.005540

0.008507

0.008630

0.008503

0.004157

0.004176

0.003831

0.009961

0.009588

0.006308

0.004221

0.004285

0.004283

0.011702

0.021409

0.012295

0.003916

0.003681

0.003569

0.005555

0.005471

0.005460

0.021044

0.012112

0.022223

0.004825

0.004057

0.004835

0.006308

0.006368

0.006482

0.004159

0.002929

0.003525

0.004067

0.003772

0.004231

0.004445

0.004571

SI2E PEX LOWPRI

$347851 N \quad 26.8$

$561366 N \quad 12.3$

$6021344 \mathrm{~N} 30.1$

$9701392 A \quad 4.2$

$9572440 \mathrm{~N} 24.6$

$20642 A$ B.

$6041772 \mathrm{~N} \quad 42.1$

$799275 \mathrm{~N} \quad 27.5$

49078 A 9.0

$1733943 \mathrm{~N} \quad 16.9$

$767332 \mathrm{~N} 25.9$

$21352752 \mathrm{~N} \quad 59.8$

$13319005 \mathrm{~N} \quad 36.0$

$6078463 \mathrm{~N} 237.7$

$1357360 \mathrm{~N} 44.0$

$2604133 \mathrm{~N} 37.0$

797475 N 24.4

$152105 \mathrm{~N} \quad 14.8$

$215784 \mathrm{~N} 13.6$

$107740 \mathrm{~N} 7.5$

$345430 \mathrm{~N} \quad 22.0$

$528363 \mathrm{~N} 34.5$

$660131 \mathrm{~N} \quad 39.0$

108198 A 10.6

214216 A 14.3

192495 A 11.6

$541599 \mathrm{~N} \quad 57.0$

$252007 \mathrm{~N} \quad 51.4$

$219106 \mathrm{~N} \quad 29.4$

07494 A 26.5

37597 A 6.3 
A2. European stocks I1sted in NXSE/AMEX in 1907

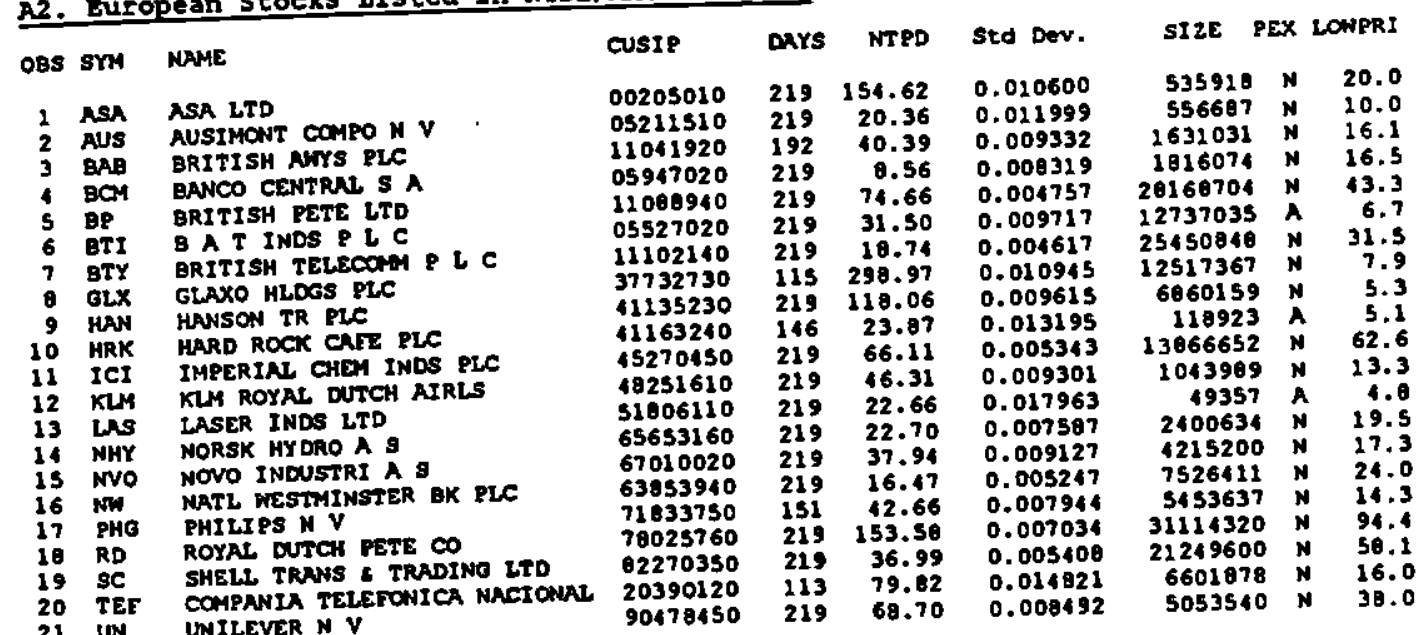

American ratching stocks in 1997

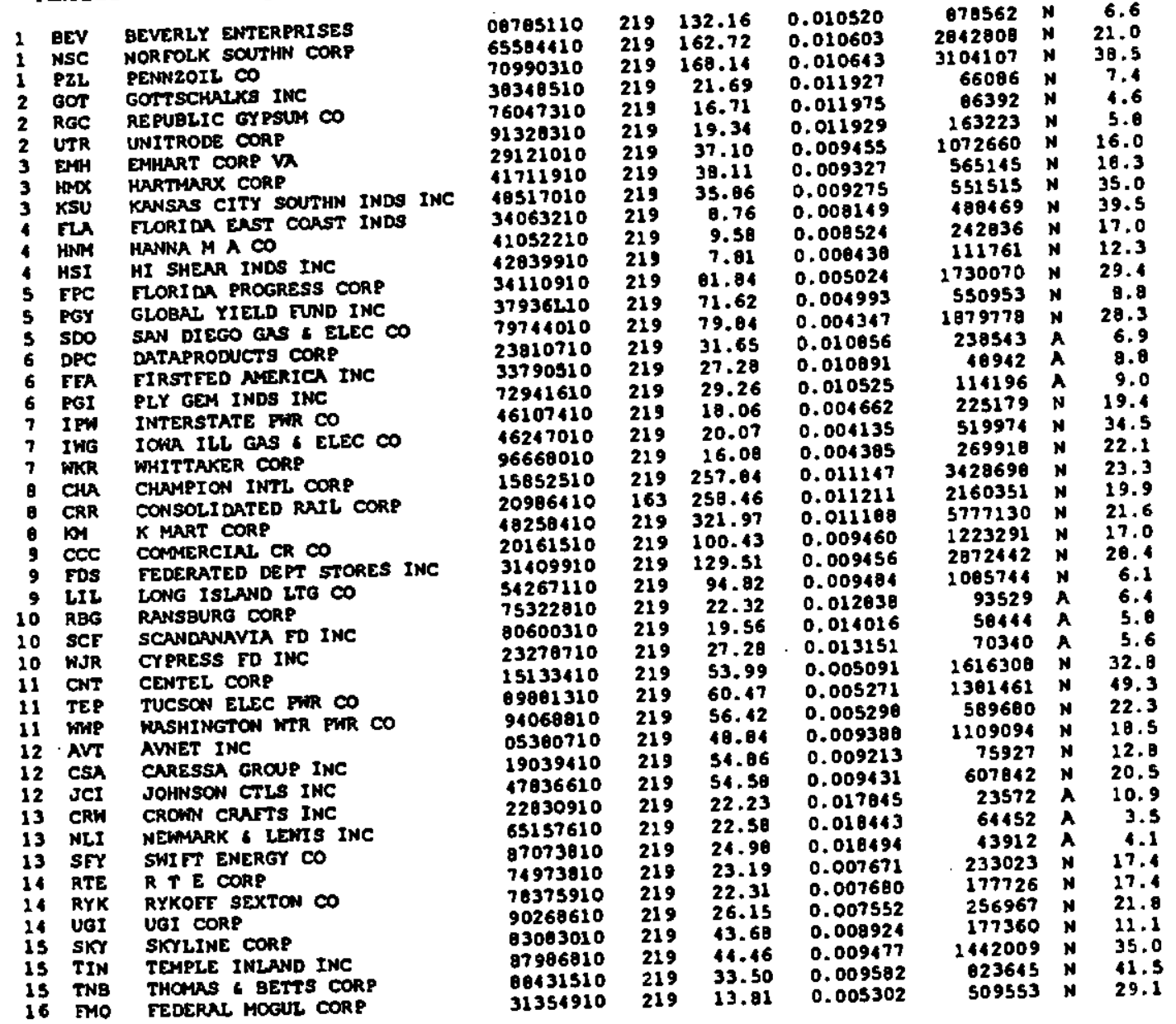




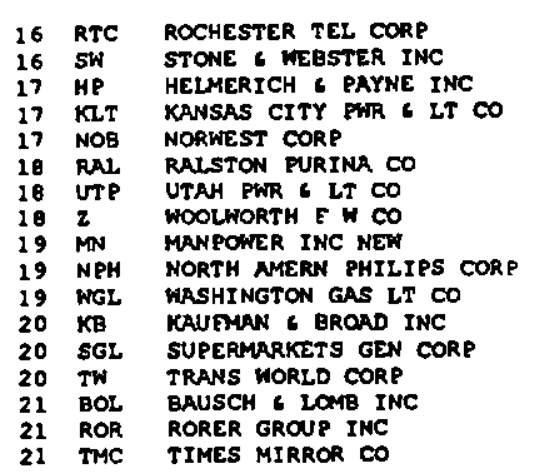

B1. Japanses stocks Listed in NYSE/AYEX in 1986

\begin{tabular}{|c|c|c|c|c|c|c|}
\hline $\begin{array}{l}77175810 \\
86157210 \\
42345210 \\
48513410 \\
66938010 \\
75127710 \\
91750810 \\
98088110 \\
56418210 \\
65704510 \\
93863710 \\
48617010 \\
66044310 \\
87311810 \\
07170710 \\
77675510 \\
68736010\end{array}$ & $\begin{array}{l}219 \\
219 \\
219 \\
219 \\
219 \\
219 \\
219 \\
219 \\
113 \\
175 \\
219 \\
219 \\
162 \\
216 \\
219 \\
219 \\
219\end{array}$ & $\begin{array}{r}19.17 \\
14.07 \\
41.22 \\
40.51 \\
49.05 \\
150.40 \\
170.09 \\
155.81 \\
36.43 \\
32.34 \\
29.61 \\
79.46 \\
76.01 \\
65.09 \\
74.37 \\
70.68 \\
78.42\end{array}$ & $\begin{array}{l}0.005162 \\
0.005093 \\
0.008154 \\
0.008135 \\
0.008118 \\
0.006680 \\
0.006749 \\
0.007213 \\
0.005610 \\
0.005071 \\
0.005460 \\
0.014393 \\
0.014455 \\
0.015628 \\
0.008325 \\
0.008308 \\
0.008437\end{array}$ & $\begin{array}{r}447986 \\
485467 \\
650234 \\
641510 \\
1247907 \\
5867946 \\
1491052 \\
2963948 \\
799830 \\
1280759 \\
408904 \\
347861 \\
1490665 \\
802520 \\
1276297 \\
995740 \\
5266628\end{array}$ & $\begin{array}{l}N \\
N \\
N \\
N \\
N \\
N \\
N \\
N \\
N \\
N \\
N \\
N \\
N \\
N \\
N \\
N \\
N\end{array}$ & $\begin{array}{r}37.0 \\
48.8 \\
17.5 \\
21.0 \\
31.8 \\
57.6 \\
20.8 \\
29.5 \\
42.1 \\
37.3 \\
19.5 \\
9.0 \\
25.1 \\
9.3 \\
30.8 \\
29.8 \\
60.4\end{array}$ \\
\hline
\end{tabular}

NTPD 43612830 50155620 57687920 03569930
236

236
236
236
28.54

44.36

9.53

33.51

52.37
Std Der.

0.003292 0.00362

0.003809

0.003424

0.004886
SIZE PEX LOWPRI

$156296944 \mathrm{~N} 35.5$ $62379856 \mathrm{~N} \quad 55.0$ $7372510 \mathrm{~N} \quad 39.6$ $59667536 \mathrm{~N} \quad 60.0$ $1769003 \mathrm{~N} \quad 18.1$

* These atocka are ano llated in London In 1986.

American Matching stocks in 1986

\begin{tabular}{|c|c|c|}
\hline $\begin{array}{l}\text { IOR } \\
\text { IPW } \\
\text { WPL } \\
\text { CNT } \\
\text { LOU } \\
\text { SNG } \\
\text { GED } \\
\text { NJR } \\
\text { WST } \\
\text { MDA } \\
\text { ORU } \\
\text { SWX } \\
\text { CCB } \\
\text { IDA } \\
\text { TEK }\end{array}$ & 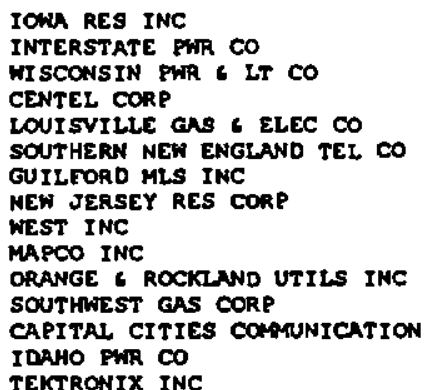 & $\begin{array}{l}46253710 \\
46107410 \\
97682610 \\
15133410 \\
54667610 \\
64348510 \\
40179410 \\
64602510 \\
95334810 \\
56509710 \\
68406510 \\
94489510 \\
13985910 \\
45138010 \\
97913110\end{array}$ \\
\hline
\end{tabular}

32.04

23.75

32.21

41.61

43.51

49.64

0.32

9.58

9.58
7.90

30.09

31.62

34.98

50.73

50.57

48.50
0.004157 0.003968 0.003831 0.004067 0.003772 0.004073 0.004040 0.003961 0.003622 0.004131 0.004445 0.004571 0.004953 0.004773 0.005020

$\begin{array}{rlr}345130 & N & 22.0 \\ 233903 & N & 21.1 \\ 660131 & N & 39.0 \\ 1524205 & N & 15.0 \\ 710030 & N & 29.0 \\ 1586952 & N & 13.0 \\ 224672 & N & 22.5 \\ 102292 & N & 25.0 \\ 231840 & N & 24.9 \\ 1432451 & N & 36.0 \\ 116816 & N & 26.3 \\ 203265 & N & 16.6 \\ 3199100 & N & 208.2 \\ 891796 & N & 22.0 \\ 1180017 & N & 54.5\end{array}$

B2. Japanses Stocks L1sted in WYSE/AMDX in 1987

CusIP
43357850
43812830
50155620
57607920
83569930

on In 1987.
7
65704510
68406510
93863710
56509710
04340310
82642510
72811710
74051210
01200710
14156010
64602510

DaYs

219

219

219

219

219
NTPO

32.00

33.44

10.96
19.89

42.01
Std Dev.

0.005170 0.005058 0.006708 0.007213 0.006136
SI2E PEX LOWPRI

$22290416 \mathrm{~N} \quad 59.3$ $0759186 \mathrm{~N} \quad 78.0$ $5248604 \mathrm{~N} \quad 18.0$ $24546272 \mathrm{~N} \quad 93.3$ $6236788 \mathrm{~N} 18.3$

+4 These stocke are also listed in London in 1987.

American Matching Stocks in 1987

$\begin{array}{llll}1 & \text { NPH } & \text { NORTH AMERN PHILIPS CORP } & 65704510 \\ 1 & \text { ORU } & \text { ORANGE G ROCKLNWO UTILS INC } & 66406510 \\ 1 & \text { WGL } & \text { WRSHINGTON GAS LT CO } & 93863710 \\ 2 & \text { MOA } & \text { MAPCO INC } & 56509710 \\ 2 & \text { SNG } & \text { SOUTHERN NEW ENGLANO TEL CO } & 04340510 \\ 2 & \text { SRP } & \text { SIERRA PAC RES } & 82642510 \\ 3 & \text { PLA } & \text { PLAYBOY ENTERPRISES INC } & 72811710 \\ 3 & \text { PRE } & \text { PREMIER INDL CORP } & 74051210 \\ 3 & \text { SGO } & \text { SEAGULL ENERGY CORP } & 01200710 \\ 1 & \text { HTN } & \text { HOUGHTON MIFELIN CO } & 14156010 \\ 1 & \text { NJR } & \text { NEW JERSEY RES CORP } & 64602510\end{array}$

0.00507 0.005185 0.005460 0.004814 0.004862 0.004994 0.006801 0.006625 0.006634 0.006634 0.007241

$\begin{array}{rlr}1280759 & N & 37.3 \\ 389971 & N & 25.0 \\ 408904 & N & 19.5 \\ 1197977 & N & 39.9 \\ 1590076 & N & 13.0 \\ 167008 & N & 18.0 \\ 115986 & N & 8.4 \\ 1114636 & N & 28.9 \\ 120291 & N & 12.1 \\ 457038 & N & 20.8 \\ 79346 & N & 16.1\end{array}$


1 PHH PHH GROUP INC

5 PIN PUDLIC SVC CO IND INC

5 RCI REICHHOLD CHENS INC

5 SCG SCANA CORP
69332010

74446510

75920010

80589810 $\begin{array}{lll}219 & 21.16 & 0.007256 \\ 219 & 19.55 & 0.006166 \\ 145 & 35.10 & 0.006136 \\ 219 & 44.37 & 0.006260\end{array}$

$588549 N$

$357119 \mathrm{~N} \quad 32.8$

$1343997 \mathrm{~N} \quad 26.5$ 